The Effect of Direct and Indirect Written Feedback on Spelling in Two Different Populations of EFL/ESL Learners

\title{
STELLA LEQUERICA
}

\author{
Research Report submitted
}

in partial fulfillment of the requirements for the degree of

Master in English Language Teaching - Autonomous Learning Environments

Directed by Carl Edlund Andersen, P.H.D.

Department of Foreign Languages and Cultures

Universidad de La Sabana

Chía, Colombia

July 2018 


\section{EFFECTS OF DIRECT/INDIRECT FEEDBACK ON SPELLING}

\section{Declaration}

I hereby declare that my research report entitled:

The Effect of Direct and Indirect Written Feedback on Spelling

in Two Different Populations of EFL/ESL Learners

- is the result of my own work and includes nothing which is the outcome of work done in collaboration except as declared and specified in the text;

- is neither substantially the same as nor contains substantial portions of any similar work submitted or that is being concurrently submitted for any degree or diploma or other qualification at the Universidad de La Sabana or any other university or similar institution except as declared and specified in the text;

- complies with the word limits and other requirements stipulated by the Research Subcommittee of the Department of Foreign Languages and Cultures;

- $\quad$ has been submitted by or on the required submission date.

Date: July 17, 2018

Full Name: Stella Lequerica

Signature:

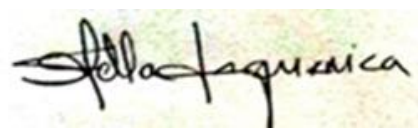




\section{Acknowledgements}

Above all, I thank God for permitting me engage and carry-out this study.

Firstly, I would like to thank my family, especially my daughter and son Tatiana and Ricardo Herrera for their patience and unconditional support all the way and all the time throughout this process of completing all the requirements for my master's degree. All their support and continuous encouragement were crucial to the success of my program, always cheering me up. My special thanks to my sister Marcia Kenny and my brother in law Thomas Kenny for their love, understanding, and encouragement. This moral support and love were invaluable to reach the finish line.

Moreover, I owe my appreciation and thankfulness to my thesis director, Dr. Carl Edlund Anderson who was always very patient and supportive. His advice and feedback gave me the confidence and understanding to carry-out this study and present its findings in this thesis work.

Finally, I thank all my professors from Anaheim University U.S.A and Universidad de la Sabana in Colombia, for their instruction and leadership in providing me the knowledge and tools to be able to complete this program, and this study. 


\begin{abstract}
This study focused on observing and analyzing the highly form-specific issue of accurate spelling by Spanish L1 learners of English with the purpose of contributing to the ongoing debate on feedback's relative efficacy, centered upon whether errors should be corrected or not and on whether feedback is effective or not. The treatment of direct and indirect written corrective feedback (WCF) was applied to spelling errors in learners of two distinct populations. An experimental action research design was appropriate to the study's comparison of the two types of written corrective feedback, direct and indirect, on learners' errors to determine their relative efficacy; and this research design permitted the establishment of relationships between the feedback treatment (direct or indirect) and spelling outcomes. The results indicated no statistically significant differences between and within groups among the two populations, suggesting that there are still no simple answers regarding feedback's effectiveness. However, although many feedback studies give limited attention to the effects of language learners' preexisting (L1) schemata, patterns in the spelling errors produced by the participants in the present study suggest that further work on the efficacy of feedback should indeed consider such issues more explicitly, as future research should consider not merely whether feedback can be valuable but how contextual factors can affect what kind of feedback (and responding to what in the learner) may be most valuable.
\end{abstract}

Key words: feedback, spelling, accuracy, spelling patterns.

\title{
Resumen
}

El enfoque de este estudio fue en observar y analizar la efectividad de dos tipos de retroalimentación escrita; retroalimentación directa e indirecta, sobre la ortografía de estudiantes hispanos del idioma inglés. El estudio trato de dar respuestas al debate de si los errores de 
ortografía se deben corregir o no, y de si la corrección de estos ha sido efectiva en la adquisición de la forma correcta. En este estudio participaron dos poblaciones sobre las cuales se aplicó dos tipos de retroalimentación escrita; retroalimentación directa y retroalimentación indirecta. Un diseño de investigación acción experimental se consideró apropiado para comparar los dos tipos de retroalimentación escrita para determinar su eficacia. Adicionalmente, este diseño de investigación permite el establecimiento de relaciones entre el tipo de retroalimentación utilizada (directa o indirecta) y los resultados de la ortografía. Los resultados indicaron la no existencia de diferencias estadísticamente significativas dentro de los grupos de las poblaciones y entre las poblaciones, sugiriendo que no hay respuestas claras en cuanto a la efectividad de una u otra forma de retroalimentación. Sin embargo, a pesar de que muchos estudios dan atención limitada a la influencia que los patrones ortográficos de la primera lengua (L1) tienen sobre el aprendizaje de una segunda lengua (L2) (en este estudio del inglés), los patrones de errores ortográficos del estudiante hispano de inglés de este estudio sugieren que más atención se le debe prestar a la eficacia de la retroalimentación en futuras investigaciones. Las futuras investigaciones no solo deben considerar si la retroalimentación es valiosa o no, sino que si puede ser más efectiva y por ende más valiosa.

Palabras claves: retroalimentación, precisión, ortografía, patrones ortográficos. 


\section{Table of Contents}

Declaration i

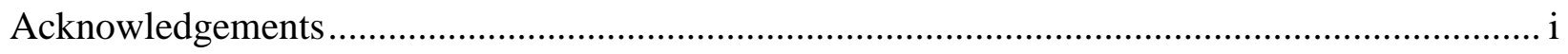

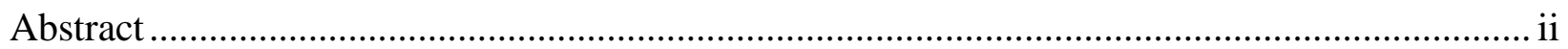

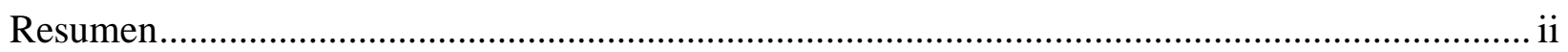

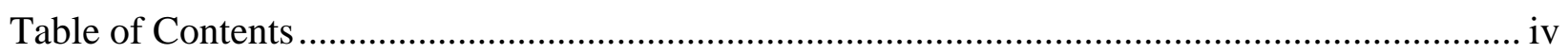

Table of Figures Error! Bookmark not defined.

Table of Tables ….......................................................................................................... vii

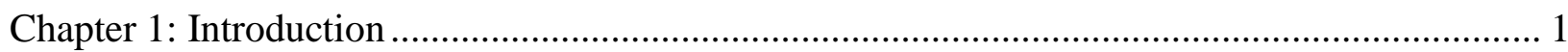

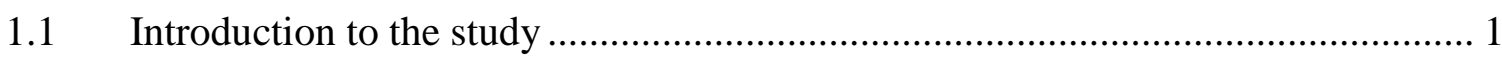

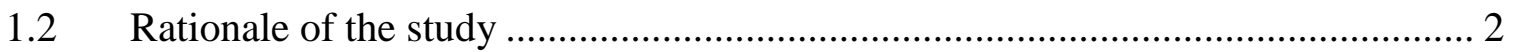

1.2.1 Rationale for the problem of the study ............................................. 3

1.2.1.1 Needs analysis and problem statement .............................. 3

1.2.1.2 Justification of the problem's significance ........................... 3

1.2.2 Rationale of the strategy selected to address the problem of the study ...... 4

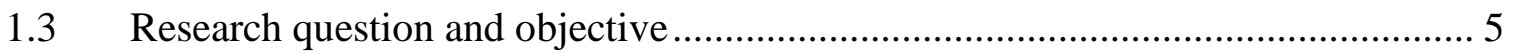

1.4 Conclusion ........................................................................................... 5

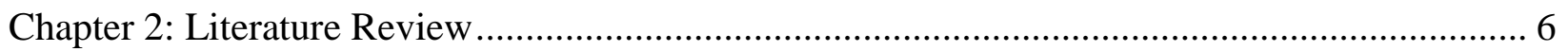

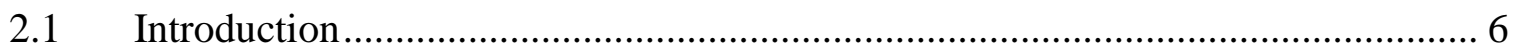

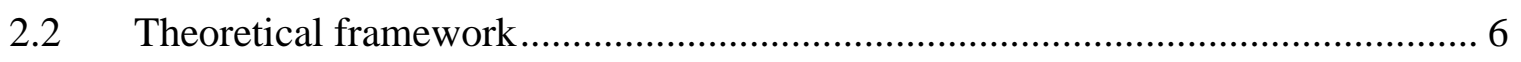

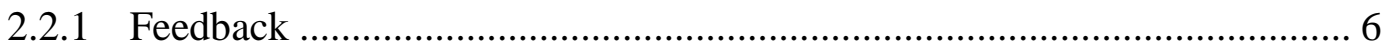

2.2.1.1 Types of feedback ......................................................... 6

2.2.1.2 Role of feedback ............................................................. 8 


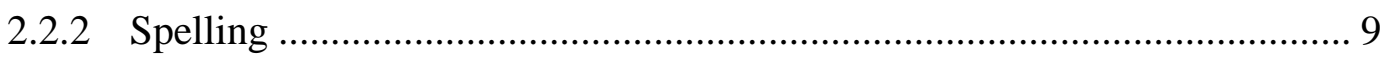

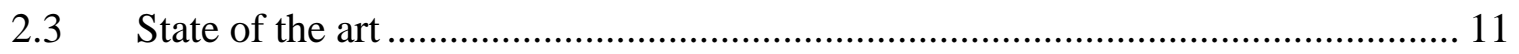

2.3.1 Previous research on teaching and learning spelling .......................... 11

2.3.2 Previous research on written corrective feedback (WCF) ..................... 13

2.3.3 Previous research on written corrective feedback (WCF) to teach/learn L2

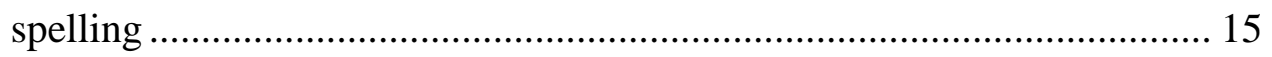

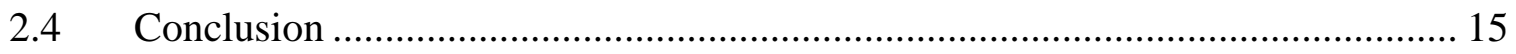

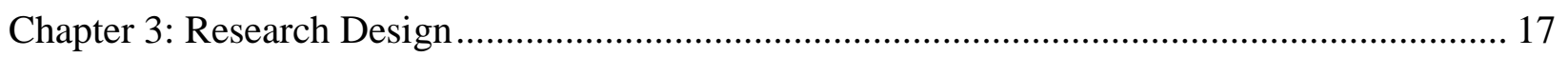

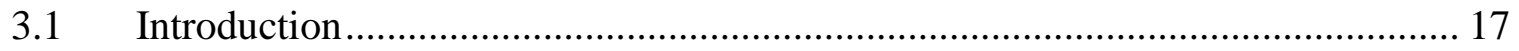

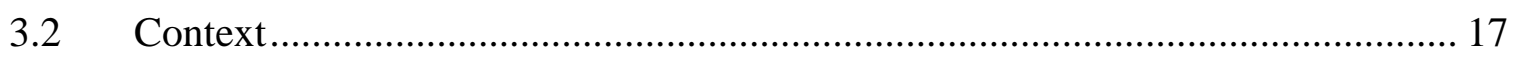

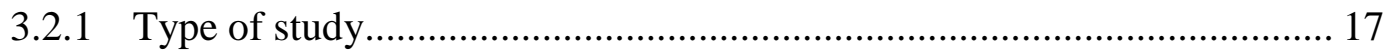

3.2.2 Participants ............................................................................ 18

3.2.3 Researcher's role................................................................... 19

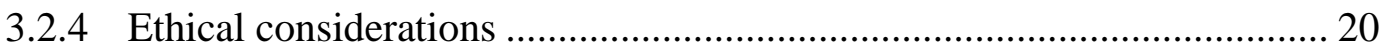

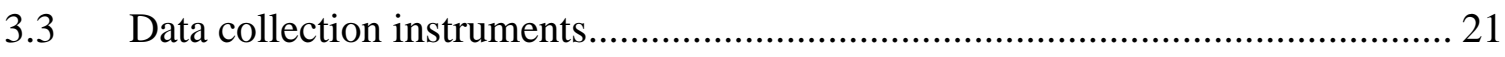

3.3.1 Descriptions and justifications ................................................. 21

3.3.1.1 Dictation.................................................................. 21

3.3.1.2 Journal entries ....................................................... 22

3.3.2 Validation and piloting................................................................. 23

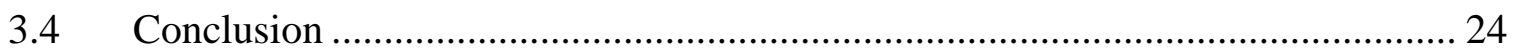

Chapter 4: Pedagogical Intervention and Implementation.................................................. 25

4.1 In

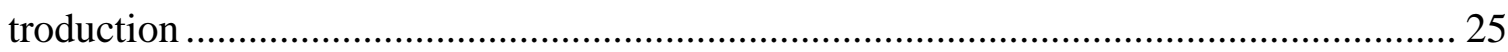




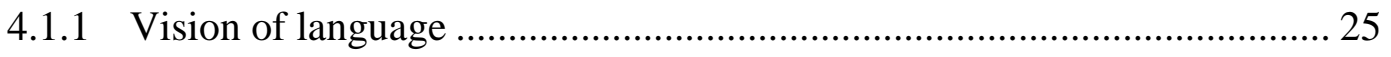

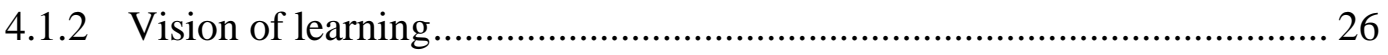

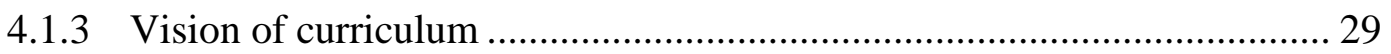

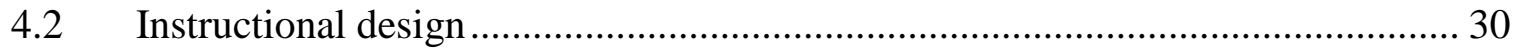

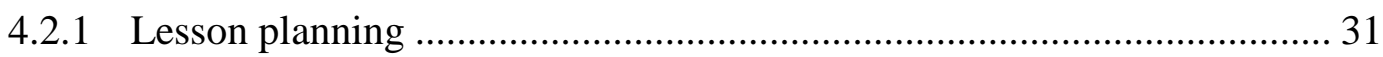

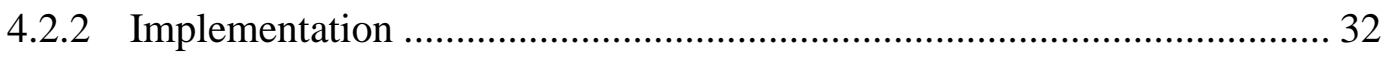

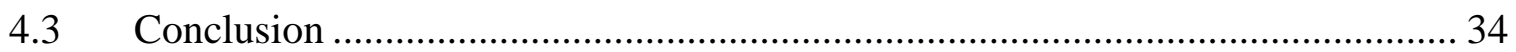

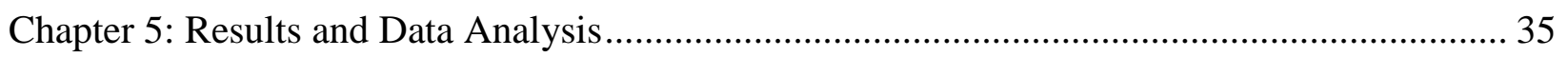

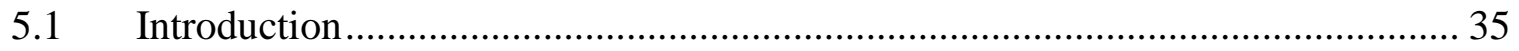

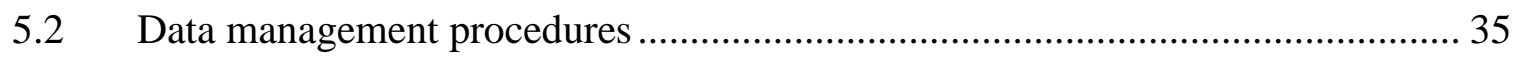

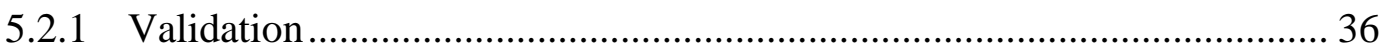

5.2.2 Data analysis methodology ...................................................... 36

5.2.2.1 Dependent and independent variables ............................ 36

5.2.2.2 One-Way ANOVA........................................................ 37

5.2.2.2.1 One-Way ANOVA work hypotheses................................ 38

5.3.1 Application of the one-way ANOVA statistical test............................... 39

5.3.2 Results on patterns of orthographical errors .................................. 40

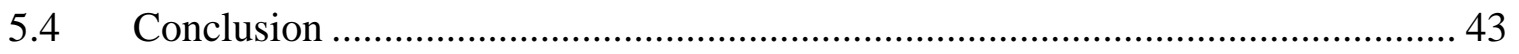

Chapter 6: Conclusions and Pedagogical Implications..................................................... 44

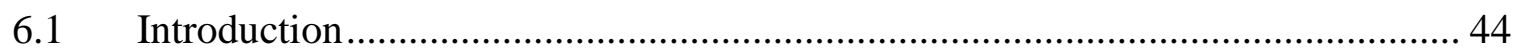

6.2 Comparison of results with previous studies' results .................................... 44

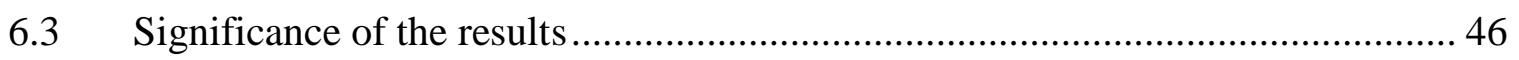

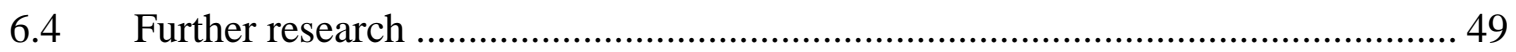


6.5 Limitations and pedagogical implications ........................................................ 50

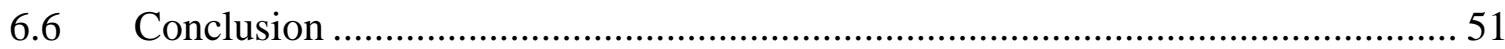

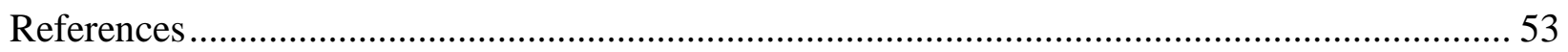

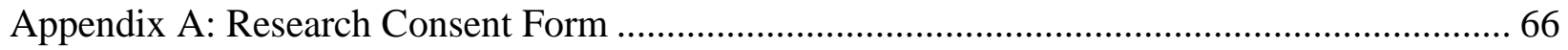

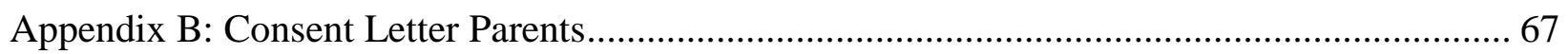

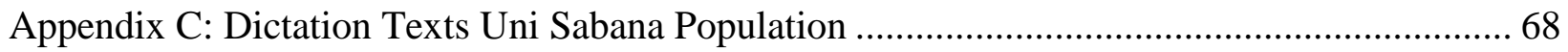

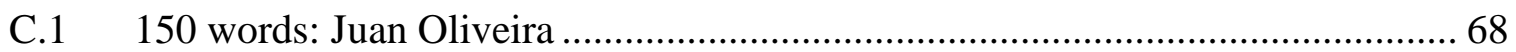

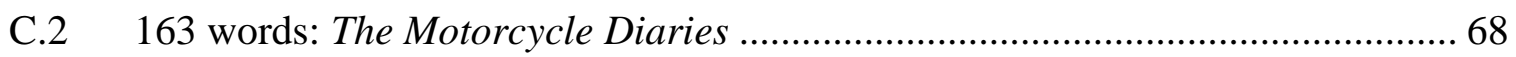

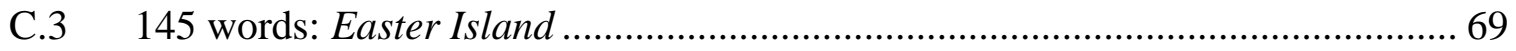

Appendix D: Dictation Texts Cumbres Population .................................................................. 70

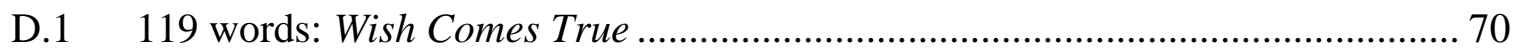

D.2 $105 \mathrm{w}$ Why I Love Thanksgiving ……………….......................................... 70

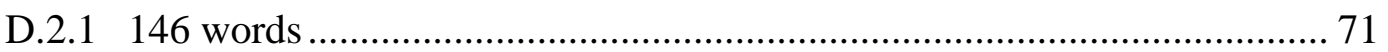

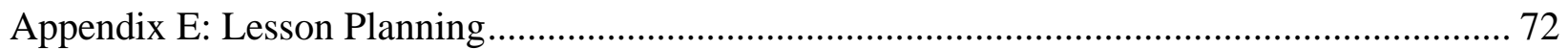

Appendix F: Tables 1-14 .........................................................Error! Bookmark not defined.

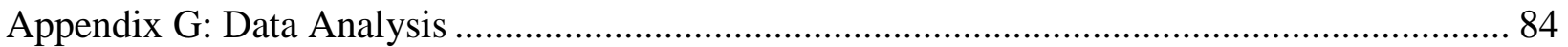

\section{Table of Tables}

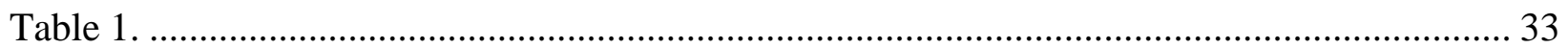

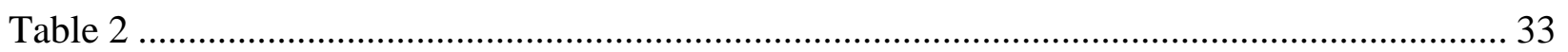

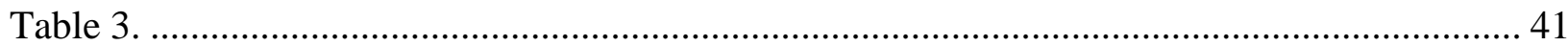

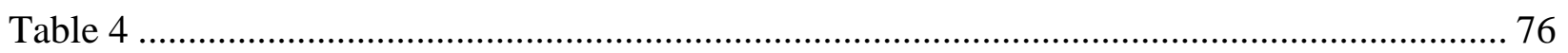

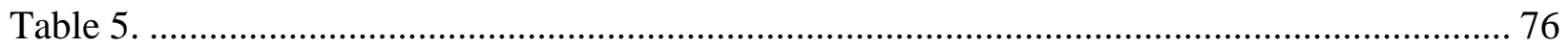




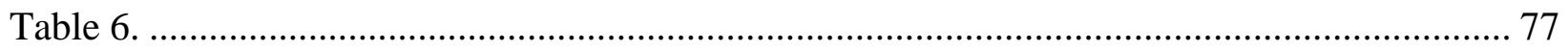

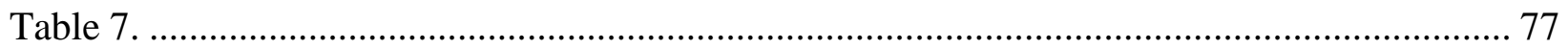

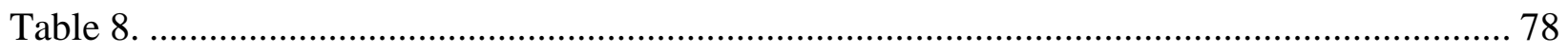

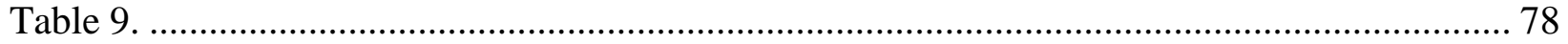

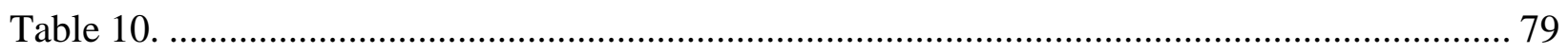

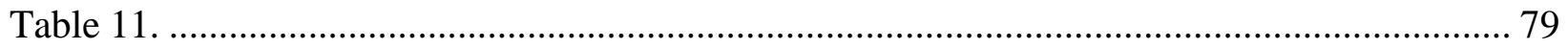

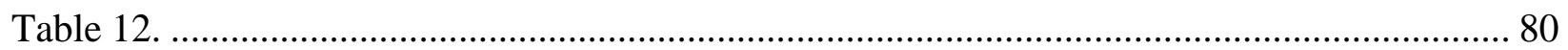

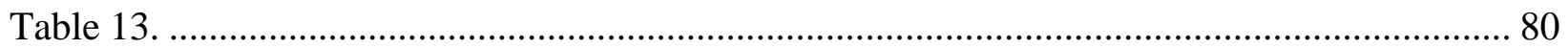

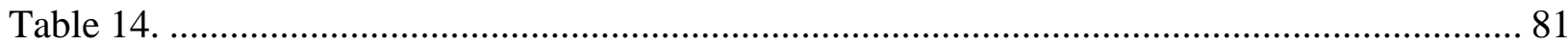

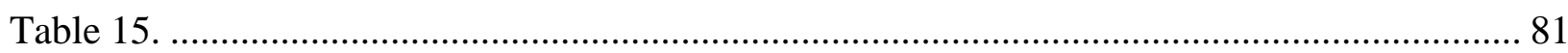

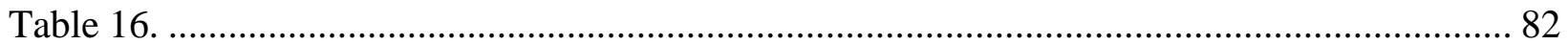

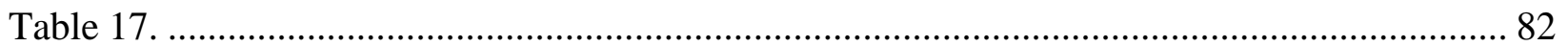




\section{Chapter 1: Introduction}

\section{$1.1 \quad$ Introduction to the study}

Accuracy, as defined by Housen and Kuiken (2009), involves a focus on linguistic form and on the controlled production of grammatically correct linguistic structures. In this respect, Maleki and Eslami (2013) argue that accuracy has a strong influence on the effectiveness of a piece of writing. Accuracy enhances clarity by facilitating the flow of ideas that aid in the unity of written texts, reducing interruptions and distractions that could affect their cohesion and make them confusing. This study focused on observing and analyzing the effect of direct and indirect written corrective feedback (WCF) on L2 English spelling. The study involved participants whose L1 is Spanish, a language with a high phoneme-grapheme correspondence (Cronnell,1985).

Corrective feedback can be given when an error comes to the attention of the editor, teacher, or instructor and must be made noticeable to learners for it to be treated and repaired. This is because people learn things to which they pay attention and of which they become aware but do not learn things to which they do not attend (Schmidt, 2010). The term WCF goes back to Hendrickson (1977) question about whether learner errors should be corrected or not. This topic has been extensively discussed by second language acquisition theorists (Bitchener, 2008), seeking to understand what can be done to help learners overcome the errors they make in the process of acquiring the target language (Bitchener \& Ferris, 2012). There has been a longrunning debate between those who believe that giving corrective feedback helps improve learners' written accuracy and those who do not, as the findings from the many experimental studies carried out have been contradictory (Guennette, 2007). Particularly, discussion has focused on how and when to give feedback, as well as its potential benefits. It is recognized that 
in English as a Second Language (ESL) and English as a Foreign Language (EFL) contexts the effectiveness of feedback that focuses on error correction is considered very important (K. Hyland \& Hyland, 2006). The issue of whether feedback is beneficial to students' development in the short and/or long term has become a major issue of disagreement in second language research, but there are no simple answers to questions such as which activities merit feedback, how and when to give feedback, and what are the benefits of feedback (K. Hyland \& Hyland, 2006). Thus, though WCF has received considerable support, disagreements about the most effective amount and kind of WCF nevertheless remain (Amrhein \& Nassaji, 2010).

\subsection{Rationale of the study}

Feedback, looked at from a broad perspective, is an action performed by a teacher in response to a learner's production with the purpose of helping the learner evaluate their performance by informing them what went well and/or badly; thus, helping the learner identify the gap between their performance and the targeted performance (Sadler, 1989). Consequently, it is hoped that through feedback the learner will be able to boost their potential awareness of what aspects of their learning and performance need attention (Chan \& Lam, 2010; Schaertel, 2012; Wiggins, 1997). Following this line of thought, the present study, with its focus on spelling as a targeted aspect of English language mechanics, sought to help Spanish L2 learners improve their spelling performance through WCF. Moreover, it contributed to the debate on the efficacy of WCF by exploring the effects of using direct and indirect WCF to treat spelling mistake and by suggesting the kinds of WCF that may be more appropriate for spelling errors/mistakes. 


\subsubsection{Rationale for the problem of the study}

\subsubsection{Needs analysis and problem statement}

A needs analysis was performed through observation, in that the teacher-researcher noticed that the participants, L1 Spanish-speakers, had difficulty producing accurately spelled English words and theorized that their challenges could be linked, at least in part, to the inconsistent soundlsymbol correspondence. As the teacher-researcher is a L1 Spanish speaker, this was something that she had also experienced first-hand. Languages with deep orthographies, such as English, are harder to learn than languages with shallow orthographies, such as Spanish, because of the mentioned inconsistencies between sound-symbol correspondences (Joy, 2017). Deep orthography refers to languages that do not have a close correspondence between sounds (phonemes) and the letters (graphemes), whereas shallow orthographies transcribe the phonemics of the language in relatively regular and straightforward fashion (Lukctela, Popadic, \& Ognjenovic, 1980).

\subsubsection{Justification of the problem's significance}

English has become a global language (Crystal, 2003). For example, 45.24\% of the world's scholarly journals and $66.55 \%$ of the world's newspapers and magazines are published in English, while $56.43 \%$ of texts on the internet are in English (Sergey, 2008). About a quarter of the world's population (around 1.5 billion people) is already competent in English, and this number has been continuously growing since the early 2000s, a rate of growth matched by no other language (Crystal, 2003). People around the world have come to depend on English for their economic and social well-being. It has penetrated deeply into various international domains such politics, business, safety, communications, entertainment, media, and education. Several domains have come to be totally dependent on it, such as that of the computer software industry (Crystal, 2003). 
Moreover, English plays a major role in most political gatherings around the globe, such as in the Association of Southeast Asian Nations, the Commonwealth of Nations, the Council of Europe, European Union, and the North Atlantic Treaty Organization (NATO). English is the only official language of the Organization of Petroleum Exporting Countries (OPEC) and the only language used in the European Free Trade Association (Crystal, 2003). Globalization and the need to be able to transmit information and ideas across borders - often through writing, for which

comprehension is aided by accurate spelling — has made learning English, as a widely known and used lingua franca, a virtual necessity for many. Finally, it is increasingly recognized that multilingualism (often involving English) has the potential to increase a person's opportunities with respect to employability and access to rights and services (Coyle, Hood, \& Marsh, 2010). Learning a foreign language, such as English, can also contribute to social cohesion by making an enriched cultural dialogue possible (Coyle et al., 2010).

\subsubsection{Rationale of the strategy selected to address the problem of the study}

The nature of the problem on which the present study focuses, the challenges of L2 spelling, demands a focus-on-form approach because spelling is a type of declarative knowledge that is favored by an awareness of the correct form. In this respect, Schmidt's (2001) Noticing Hypothesis points out that learning is preceded by conscious awareness, in this case of the correct spelling, which arises prior to intake. For this reason, explicit WCF was chosen to treat spelling errors as it creates awareness about the mistake by clearly pointing out that a given issue needs correction. Both direct and indirect WCF were used in different instances in an effort to determine which type was more effective. 


\subsection{Research question and objective}

The objective of the present study was to provide WCF to English language learners on their English spelling accuracy so as to contribute to the ongoing debate about the relative efficacy of such feedback and (granted this) the most effective way (direct or indirect) to give it. The research question that guided the study was: How does addressing spelling errors through the provision of direct and indirect WCF affect the spelling accuracy of L2 English primary-level (CEFR B1) and university-level (CEFR A2) learners?

\subsection{Conclusion}

The need for further investigation on the most effective type of WCF for supporting the learning of accurate spelling, focused on L1 Spanish learners of English, was made evident through the teacher-researcher's observations of her learner populations' apparent difficulties in coping with spelling certain English phonemes when they heard the words containing these. It was theorized these difficulties were due at least in part to the inconsistent sound-symbol correspondence of English orthography. Therefore, the teacher-researcher sought to examine the relative efficacy of giving direct and indirect WCF to help L2 learners of English to overcome spelling errors. 


\section{Chapter 2: Literature Review}

\section{$2.1 \quad$ Introduction}

Written corrective feedback (WCF) is a controversial area in educational research, as varied results concerning its efficacy have made it difficult to reach a consensus. Many studies have attempted to find what type of feedback, or combination of types of feedback, is most effective. Results have, however, been inconclusive; some findings seem to show that WCF can be beneficial in certain circumstances, yet others appear to show WCF offers no benefits under any circumstances. This chapter examines the existing research on WCF, highlighting its controversial nature, as well as on the teaching and learning of spelling, with a focus on the most important factors affecting L1 Spanish learners of L2 English orthography.

\subsection{Theoretical framework}

\subsubsection{Feedback}

As stated by Timperley and Timperley (2007), in most cases, feedback has been conceptualized as an event in which information about an individual's performance or progress is communicated by an instructor or evaluator. Feedback is thus, a consequence of performance (Hattie \& Timperley, 2007). Feedback helps learners keep track of their own strengths and weaknesses and helps teachers make pedagogical decisions based of students' progress (Sadler, 1989).

\subsubsection{Types offeedback}

The question of whether any one type of corrective feedback is better than another is a topic that has attracted enormous interest. Yet despite all the research directed toward this issue, there are still no clear answers to questions about relative efficacy of different types of feedback 
or even feedback in general (K. Hyland \& Hyland, 2006). Amongst the types of feedback studied have been:

1. Direct feedback: the teacher provides the student with the correct form.

2. Indirect feedback: the teacher indicates that an error has occurred but does not provide the correction.

3. Metalinguistic: the teacher provides some kind of metalinguistic code for the error/mistake by commenting or questioning about his/her mistake. If a student says, "he like to eat pizza", the teacher would ask do we say, "he like?"

4. Focused feedback: concerns whether the teacher attempts to correct all errors or just focuses on one or two selected errors.

5. Electronic feedback: the teacher identifies an error and provides a hyperlink, or other electronic resource, that explains the correct form.

6. Reformulation: a native speaker reworks a student's text to make it as close as possible to native-like language.

7. Written corrective feedback: When an error comes to the attention of the editor, teacher, or instructor and must be made noticeable to learners by marking it on his/her paper for it to be treated and repaired.

In this study, the type of error correction known as WCF (Bitchener, 2008), which can be either direct or indirect, was chosen to address spelling problems with students' L2 writing. As pointed out by Schmidt (2001) in the context of his Noticing Hypothesis (section 2.2.1.1), learning is preceded by conscious awareness, which must thus arise prior to intake. Accordingly, this conscious awareness may be generated by the direct or indirect WCF on a rule-governed linguistic form, such as the correct spelling of a word, and should help narrow the gap between 
the erroneous linguistic form embedded in the learner's interlanguage and the correct target language form. In this respect, Gas and Varonis (1994) emphasize that awareness of the gap between the erroneous and the target-like linguistic form triggers modifications of interlanguage towards the target-like structure.

\subsubsection{Role offeedback}

Overall, feedback has been widely perceived as a way to encourage and consolidate knowledge (K. Hyland \& Hyland, 2006). Particularly with regard to the development of L2 writing, Hyland and Hyland (2006), have regarded feedback as essential, not least for its role in student's motivation. Borkaoui (2007) argues that teachers should raise students' awareness about the importance of visualizing their texts from a reader's perspective, as well as encouraging students to reflect on and self-assess their own writing. Feedback has been argued to help foster such actions by raising awareness about the erroneous form (F. Hyland, 2003; K. Hyland \& Hyland, 2006; Schmidt, 2010).

With respect to students' choice, surveys done in foreign-language learning settings generally indicate students' preference for their teacher's written feedback over other delivery forms (such as oral or peer feedback), as they look up to their teachers and have confidence in teachers' knowledge of and skills in English (Saito, 1994). However, despite L2 students' apparent confidence in their teachers' written feedback, its contribution to either short or longterm writing skill development remains unclear. K. Hyland and Hyland (2006) have raised questions about the effectiveness of WCF for L2 learning, such as:

1. Does WCF make a difference to students' writing?

2. If so, in what areas? 
3. Can error correction and form focused feedback have long-term benefits for students' writing?

Ultimately, despite a positive perception of WCF amongst learners regarding its role in supporting their L2 learning process, current research such as Bitchener and Ferris (2012), has not yet been able to demonstrate its effectiveness unequivocally.

\subsubsection{Spelling}

Spelling is a concept that refers to information stored in memory about the correct way to represent words in written form; in other words, orthographic knowledge or knowledge of the correct way to write a language (Apel, 2011). With regard to the application of such knowledge, various studies have acknowledged the existence of orthographic patterns in learners' minds that affect their graphemic production of written language (Conrad, 2008; Georgiou, Parilla, \& Kirby, 2009; Grossi, Murphy, \& Boogan, 2009; F. Hyland, 2003; Kirby, Desrochers, Roth, \& Lai, 2008; Ouellet \& Senechal, 2008; Tong, Mc Bride-Chang, Shu, \& Wong, 2009). Apel (2011) argues that when there is mental graphic representation of a word, one should be able to write that word correctly; but when the pattern is not followed, or is not there, spelling errors occur. The patterns in question can be of several kinds, including: knowledge of the sound each letter represents, knowledge of sounds that go beyond one to one correspondence, knowledge of how letters can or cannot be combined, and knowledge of rules that indicate the position of certain letters in words.

With respect to knowledge of the sound each letter represents, Kemp (2006) analyzed the spelling of words containing sounds for which a learner might easily confuse the correct use of letters. For example, standard English orthography can represent the phoneme /z/ as both $\langle z\rangle$ and $\langle\mathrm{s}\rangle$; thus, learners might misspell words like busy and noisy (not illogically) as $\langle$ buzy $\rangle$ and $\langle$ noizy〉. English orthography is notorious for its non-phonemic nature, largely a consequence of 
the spelling system becoming fixed before significant sound changes that shaped its current pronunciation had taken place. A diphthong such as /ei/ can be written $\langle$ ay $\rangle$ (as in may/'mei/), while another such as /ai/ can be written $\langle\mathrm{i}\rangle$ (as in light/'lart/). The simple /l/ phoneme in doll /'dol/ and bell /'bel/ is written as if a germinate, $\langle 11\rangle$, while the /f/ phoneme can be represented orthographically in a variety of ways including $\langle\mathrm{f}\rangle,\langle\mathrm{ph}\rangle$ (as in paragraph /pærəgra:f/), and $\langle\mathrm{gh}\rangle$ as in laugh /'la:f/. On the other hand, certain orthographic letter combinations do not typically occur in English spelling, such as $\langle j q\rangle$ or $\langle w z\rangle$. Of course, English spelling is ultimately largely rule-governed, though most conventionally literate L1 speakers have internalized such rules without being aware of them. For example, an $\langle a\rangle$ inevitably represents the diphthong /eI/ when it appears before the combination 〈nge〉 as in range /'reInd3/. Many English L1 speakers presented with a nonexistent form such as $\langle$ bange $\rangle$ might well decide to pronounce it /'beind3/ without being able to explain why clearly. In any event, such circumstances lead to English spelling being considered a deep and irregular orthographic system, as it has fewer one-to-one lettersound correspondences than most other languages (Ouellet \& Senechal, 2008) and is accordingly less pattern-based than many other orthographies (Bolger, Minas, Burman, \& Brooth, 2008; Hilte \& Reitsma, 2008; Verhoeven, Schreuder, \& Baayen, 2006).

Such complexities can create considerable difficulties for English-language learners in their attempts to spell accurately. In the present study, the teacher-researcher sought to focus on the difficulties that L1 Spanish learners of English had with learning to spell words in the L2 accurately in order to understand the particular challenges for and vulnerabilities of this kind of English language learner. 


\subsection{State of the art}

\subsubsection{Previous research on teaching and learning spelling}

Error correction is an inherent aspect of the teacher's profession and, therefore central to teaching. Error correction is the most common form of feedback presently used (C. G. Van Beuninge, Dejong, \& Kuiken, 2012). Many educators are concerned about what kind of error treatment or correction should be used and have legitimate worries about whether errors should be corrected or not. Truscott $(1996,1999,2004,2007)$ has doubted teachers' capacities to provide adequate feedback, objecting that WCF neglects important aspects of foreign or secondlanguage acquisition (FLA/SLA), such as the complicated nature of the interlanguage system and the complex and gradual underlying process that takes place before acquisition (Truscott, 1996). Moreover, he adds that correcting student errors might be counterproductive because the awareness created by emphasizing such errors might inadvertently encourage students to avoid more complex structures (Truscott, 2007). Thus, he argues, WCF should be avoided. Instead, the time and energy spent by teachers and students on correcting errors would be more effectively used for other activities, such as additional writing tasks. Truscott (1996) claims prompted a response from Ferris (1999), who argues that Truscott's work was premature, lacking sufficient evidence and suffering from methodological flaws. Moreover, Truscott's assertions led to subsequent research such as that of Ferris and Roberts (2001) that, in contrast, does seem to show that WCF appears to improve accuracy in textual revisions. Further studies such as those of Bitchener (2008), Bitchener and Knoch (2008a), and Bitchener and Knoch (2009) have also argued that, over time, WCF can indeed help improve accuracy when writing new texts. WCF has benefits beyond the immediate provision of merely temporary knowledge (as had been argued by Truscott) and could indeed influence and contribute to the development of explicit 
declarative knowledge, which has been shown to affect accuracy gains positively (Bitchener \& Knoch, 2010). On the other hand, Bitchener, Young, and Cameron (2005), found that L2 learners who produced accurate linguistic forms on one occasion might not do so on other similar occasions. Such findings seem to align with earlier discoveries, such as the fact that learners create their own unique language systems (interlanguage) in the process of learning an L2 (Ellis, 1994). The creation of such interlanguage seems to underlie the acquisition of essentially any given linguistic feature.

Generally, research in the field of English language literacy skills directed toward English language learners has been limited and has only started to show progress relatively recently (Slaven \& Cheung, 2004). Nevertheless, Templeton and Morris (2000) have identified that research on English-language spelling for speakers of other languages is an area that requires more research. There has nonetheless been some work in this area, particularly with younger learners of English, that seems to suggest some explanations for the challenges with spelling experienced by this population. Fashola, Drum, Mayer, and Kang (1996) argue that orthographic mistakes tend to occur when the same sound in both L1 and L2 is represented orthographically by a different letter. For example, the phoneme $/ \mathrm{h} /$ is represented in some varieties of Spanish (including Colombian Spanish) as $\langle\mathrm{j}\rangle$, while the same phoneme in English is represented by the letter $\langle\mathrm{h}\rangle$; thus, the English word happy /'hæpi/ might be spelled as 〈japi by a Spanish learner of English. In this respect, Ehri (1986) argues that spelling mistakes attributable to phonetics occur when the learner comes across a new sound that is not stored in their long-term memory. He also observes that children often rehearse parts of a word's sounds (phonemic units) in memory and then associate these with a letter or letter combination that is familiar to them (Fashola et al., 1996), thereby suggesting an explanation for subsequent spelling mistakes. A similar 
understanding was reached by Raynolds and Uhry (2010), who suggest that spelling difficulties amongst young learners of an L2 derive largely from a mismatch between the phonological representations in their L1 and the L2. For example, the English phoneme $/ \mathrm{J} /$ is non-existent (or at best marginal) in most varieties of Spanish and can be interpreted as $/ \mathrm{t} \mathrm{f}$, a sound typically represented $\langle\mathrm{ch}\rangle$ in Spanish orthography. Consequently, if the $/ \mathrm{f} /$ phoneme (and its standard orthographic representation in English $\langle\mathrm{sh}\rangle$ is not stored in a learner's long-term memory (Fashola et al., 1996), a Spanish-speaking learner of English might spell the word she / $\mathrm{j} /$ as $\langle$ chi $\rangle$.

In the present study, the teacher-researcher observed that similar transfer issues seemed to be at work in both of her sample populations, the younger (9 to 10 years old) and older groups (with an average age of 19), possibly helping to explain their spelling difficulties.

\subsubsection{Previous research on written corrective feedback (WCF)}

Researchers such as Bruton (2009) and Evans, Hartshorn, McCollum, and Wolfersberger, (2010) have highlighted the inherent limitations of current research on WCF and attribute these to an array of contextual factors that, according to them, add complexity and limit results. Since Truscott's (1996) claim that feedback should be abandoned because it is not just ineffective but indeed harmful, the call for longitudinal evidence of the efficacy of WCF for ESL/EFL writers has been made repeatedly. Nevertheless, the results of studies that have been made have themselves varied greatly, and it must be admitted that further investigations are required before conclusions can be made.

Many studies have investigated whether certain types of feedback or combinations of feedback are more effective than others. Most studies have distinguished between the effectiveness of two types of WCF: direct (explicit) and indirect (implicit) (Bates, Lane \& Lange, 
1993; Ferris \& Hedgcock, 1998; Hendrickson, 1980; Lalande, 1982). When direct WCF is used, learners are provided with the correct linguistic form or structure by the teacher, this being written in near the linguistic error, which is itself crossed out, underlined, or circled by the teacher. With indirect WCF, an error is called to the attention of the learner by highlighting, circling, or underlining, but the correct form is not provided; it is expected that the learner comes up with the correct form. Studies that have investigated the value and usefulness of these feedback approaches have compared the results of: a) direct and indirect types of WCF, b) different types of indirect feedback, or c) different types of direct feedback (Bitchener \& Knoch, 2009). Of studies that have compared direct and indirect feedback, Lalande (1982) reported merits for indirect feedback and Chandler (2003) reported positive results from both direct and indirect feedback while Semke (1984) and Rob, Ross, and Shortreed (1986) reported no differences between the two approaches. These differing results have made it difficult to reach any confident conclusion.

Nevertheless, in the years since Truscott's heated calls for its abandonment (Truscott, 1997, 2010), the body of researchers testifying to the general benefits of WCF has continued to grow (Bitchener \& Knoch, 2008b, 2010). Other comparative studies such as those carried out by Fazio (2001) and Lalande (1982), investigated whether certain types of feedback are more effective than others. Bitchener and Knoch (2008b) and Ellis, Loewen and Erlam (2006) investigated the effects of corrective feedback in the areas of grammar, pronunciation, and writing accuracy. Ellis, Loewen and Erlam (2006) investigated the effects of different types of explicit and implicit corrective feedback on the acquisition of the English past tense suffix -ed (in its most common form). Nevertheless, as mentioned, all these studies with their multiple variant outcomes have led to no conclusion other than that there may be some problem in the 
approaches to the research on feedback that has been carried out thus far and, at the very least, the lack of a decisive consensus on the issue offers reason to continue researching it.

\subsubsection{Previous research on written corrective feedback (WCF) to teach/learn L2 spelling}

Notwithstanding the fact that there have been a considerable number of studies on the issue of improved accuracy in writing, such Bitchener and Knoch (2008a, 2009, 2010), Bitchener (2008), and Ferris and Roberts (2001) (see section 2.3.2), somewhat surprisingly there seems to have been little or no work specifically focused on the use of WCF in teaching English spelling, much less to L1 Spanish learners of English. As mentioned previously in section 2.3.1, research on literacy skills for learners of English has been limited (Slaven \& Cheung, 2004), perhaps particularly in the area of English-language spelling, which thus represents an area requiring more research (Templeton \& Morris, 2000). Hence, the present study sought to address this gap, by examining the effect on orthographic accuracy of providing direct and indirect WCF on English spelling mistakes made by Spanish learners of English.

\subsection{Conclusion}

Clearly, the lack of consensus, despite extensive research, on the relative value or efficacy of feedback represents a gap that has yet to be filled (Goldstein, 2005, 2006; K. Hyland \& Hyland, 2006). Studies have so far failed to provide clear evidence as to whether written corrective feedback (WCF) helps improve linguistic accuracy or not (D. R. Ferris, 1999; Guennette, 2007). Research on feedback has been dynamized by these inconclusive and mixed results; however, there is still a need to look for ways to provide feedback that works effectively and consistently. The present study focused on the highly form-specific issue of accurate spelling (in a standardized orthographic system, a word is either spelled correctly - that is, in 
accordance with an often-unique acceptable form—or it is not) with the intention of reducing ambiguity about the relative efficacy of the feedback provided. This required the design of instruments appropriate to both the context of the participants and the type of data needed to answer the research question (see section 1.3), which is discussed in Chapter 3. 


\section{Chapter 3: Research Design}

\subsection{Introduction}

Though previous research on the relative efficacy of WCF has remained inconclusive (see section 2.3), the quest for more definite answers continues to drive research on the issue. The present study sought to contribute to the debate by examining the relative effects of providing WCF on English spelling errors made by L1 Spanish-speaking learners of English. The focus on a highly form-focused issue — of orthographic correctness, in this case - was considered to be an approach that could reduce ambiguity about the accuracy of learner performance. To gather data appropriate to answering the research question (see section 1.3), it was necessary to consider the nature and context of the study, including the characteristics of the participants, in order to design appropriate instruments. Separate groups of participants with slightly different characteristics were selected, to provide additional corroboration of the results. Ultimately, a fairly straightforward approach of providing English-language oral dictations, which the participants sought to transcribe in orthographically correct written English, was chosen as a means of testing learners' understanding of phonological-orthographical correspondences in target language's standard written form.

\subsection{Context}

\subsubsection{Type of study}

This experimental action research study examined the use of WCF to address the participants' existing difficulties with producing accurate English spelling in order to shed light on the relative efficacy of this approach, which has been widely but inconclusively debated through several decades of prior research (see section 2.3). With respect to this, Burns (2010) observes that one of the main aims of action research is to identify problematic situations or 
issues that are worth looking into more deeply and systematically. Moreover, in action research, the teacher becomes the investigator or explorer of their own teaching context (Burns, 2010), a methodology appropriate to the context of the present study.

In the present study, an experimental approach was used to compare the relative effectiveness of direct and indirect WCF on learners' L2 spelling. Merriam (1998) notes that quantitative research often includes description, interpretation, and understanding of something by identifying patterns such as categories. Moreover, a quantitative approach is considered suitable because it invokes findings that are precise (Merriam, 1998), and in this study the focus was on quantity (of errors) before and after the pedagogical treatment; thus, a numerically oriented quantitative approach was considered appropriate. Studies that have used a similar experimental design to compare direct and indirect corrective feedback (mentioned in 2.3.2) are Lalande (1982), Chandler (2003), Semke (1984), and Rob, Ross, and Shortreed (1986).

\subsubsection{Participants}

This study used two distinct populations, henceforth identified as Population 1 and Population 2, each of which contained three groups, identified here with the following alphanumeric codes: Population 1 Group 1 (P1G1), Population 1 Group 2 (P1G2) Population 1 Group 3 (P1G3), Population 2 Group 1 (P2G1), Population 2 Group 2 (P2G2) Population 3 Group 3 (P3G3).

Population 1 consisted of students drawn from three English as a foreign language (EFL) classes at a private university in Colombia. From each EFL class, 10 students participated, for a total of 30 in this population's three groups. The average age of participants in Population 1 was 19 years, and their English language levels ranged between A1 and B2 according to the Common European Framework of Reference for languages -CEFR- (Council of Europe, 2001). Although 
the classes were homogeneous from an ethnic standpoint (as all the students were Colombians), the participants came from a mix of socioeconomic backgrounds. Some were from small, mainly rural villages (lower socioeconomic status), while others came from affluent families in urban Bogotá (higher socioeconomic status). Competence in English as an additional language is very important at the participants' university. Students must obtain a satisfactory score in an international English proficiency exam such as TOEFL (Test of English as a Foreign Language) such as a of 61 in its IBT version to be considered competent to graduate from their degree programs. At the time the study took place, the participants in Population 1 were receiving three hours of face-to-face English-language classroom instructions each week and were expected to dedicate an additional hour each week to English-language learning through asynchronous internet sessions provided in the university's Moodle platform.

Population 2 consisted of 30 younger learners aged 9-11 at a private Catholic school in Chía, Colombia. At the time of data collection, these students' English language levels ranged between A2 and B1 according to the CEFR (Council of Europe, 2001). This population was homogeneous from both an ethnic and a socioeconomic standpoint: all the students were Colombians and came from higher socio-economic backgrounds. During the study, the students were receiving 11 hours of English-language input in focused classes each week, plus an additional 4 four hours of content-based instruction through English (Science was taught in English).

\subsubsection{Researcher's role}

The teacher-researcher's role in this study was to observe, plan, act, and reflect. Kember (2000) characterizes the teacher's role in terms of actions taken at different stages in the research. In the observing stage, the teacher-researcher identified the problem; that is, something that was not 
working well and that needed to be changed or improved. In the planning stage, actions geared towards improving or changing were defined. This was then followed by the acting stage, which involved the carrying out of the planned course of action. Finally, in the evaluation stage, the teacher-researcher analyzed the results of the action(s) in order to understand them, make interpretations, and produce insights. These were thus the stages followed by the teacherresearcher in this study.

By carrying out the above-mentioned research sequence, the teacher-researcher encountered aspects of feedback that had not yet been clearly determined; these, the teacherresearcher sought to visualize through the analysis of quantitative data. This approach aligns with the positivist paradigm tradition as depicted by Wallerstein et al. (1998), in which social reality is considered an objective entity and, as such, it is the job of scientist (researcher) disclose it.

\subsubsection{Ethical considerations}

To take advantage of the results of research without hurting anyone, it is important to ensure that the risks are reasonable in relation to the probable benefits. In the social sciences, it is sometimes thought that strict ethical considerations are not necessary, as social science is generally viewed as not posing physical harm to participants. Nevertheless, any research has the potential to cause harm (De Wet, 2010). Such harm may not be as direct or visible as physical injury, but there can be psychological harm, including unfulfilled expectations, disappointment, and unexpected or erroneous representations or interpretations. Moreover, as Jacobson, Gerwurtz, and Haydon (2007) observe, the harm may not occur within the course of the research itself but might only become apparent later.

To conduct sound research, it is important to build a relationship based on trust between the researcher and the subjects involved to ensure the subjects' effective collaboration in the 
study. Part of the process of building this trust involves obtaining the subjects' informed consent, and for this to occur, the researcher must ensure that the subjects understand the nature and purpose of the investigation and assure them that ethical protocols will be followed throughout. Indeed, Murphy and Dinwall (2007) assert that research should only be carried out with consenting participants. However, ethical procedures in the social sciences are not as clear cut as they are in biomedical or clinical research, where a "tick-box" procedure is easy to follow. In social sciences, such "tick-box" procedures are seldom practical, due to the many subtleties that accompany social science research (De Wet, 2010). Consequently, informed consent should be based on an "ethics in process" protocol (Kim, Ubel, \& De Vries, 2009, p. 534), a more dynamic and flexible approach better adapted to the nature of social science research.

In the present study, the researcher informed the directors of the participating institutions by means of consent letter. In the case of the institution at which the participants were minors, a consent form was additionally acquired from children's parents (see Appendix A and Appendix B).

\subsection{Data collection instruments}

\subsubsection{Descriptions and justifications}

\subsubsection{Dictation}

Dictation is the activity of writing down what is orally spoken or read aloud (Mohammad \& Benis, 2014). Richard and Schmidt (2002) define dictation as a technique used in both language teaching and language testing in which a passage is read aloud to students or test takers with pauses during which they must try to write down what they hear as accurately as possible. (p. 157). In this study, dictation refers to activities in which the students attempted to transcribe a passage of text that they heard the teacher-researcher read aloud to them. The student artifacts 
produced from these dictation activities were the main data collection instruments (see Appendix $\mathrm{C}$ and $\mathrm{D}$ for texts used in the dictations). This process offered advantages for the teacherresearcher and students, including: a) it permitted the teacher-researcher to focus on a single error category and b) for students, words were presented in a context. In this respect, Kidd (1992) argues that dictations encourage students to attend not only to words' forms but also their meanings, as the words are encountered in context. The control of this factor (the focus on one error category) permitted the teacher-researcher to draw conclusions based solely on the application of the feedback treatments without the distractions of other grammatical and structural error categories. The analysis of the data collected revealed learners' relative knowledge about the phoneme-grapheme correspondence in English and the degree of control they had over usage of that knowledge.

Moreover, using dictations can also serve as a consciousness-raising mechanism Kidd (1992) about spelling. This helped the teacher-researcher determine whether a given participant's lack of competence in spelling was due to their developmental stage that is, if they were still struggling to make sense of speech by continually formulating and reformulating hypotheses about the target structure (Oller, 1978) or some other factor, such as ineffectiveness of the feedback treatment.

\subsubsection{Journal entries}

Keeping field notes is a way of reporting observations, reflections, and reactions to classroom problems, and such notes should ideally be written as soon as possible after a lesson (Hopkins, 1985). Field notes can be "documented regularly in a personal journal and then analyzed for recurring patterns or salient events" (K. Bailey, 1991, p. 215). In the present study, the teacherresearcher made journal entries to record information about learners' attitudes (such as 
nervousness, boredom, uneasiness, frustration, or confidence) observed during the dictation sessions. The information recorded in the journal entries revealed the mentioned non-linguistic aspects of participant attitudes towards the dictations.

\subsubsection{Validation and piloting}

Validating research instruments helps researchers assure that their collected data measures what they intended to measure and that the research provides an authentic representation of reality, with reliable findings and conclusions (Sanders \& Banda, 1997). Kelley, Clark, Brown, and Sitzia (2003) argue that a research instrument should be tested on a pilot sample of members from the research population, and Gudmundsdottir and Utne (2010) observe that piloting provides researchers with an important opportunity to learn from the process and reduce mistakes when implementing and collecting data. In this study, the teacherresearcher validated the research instruments by piloting them with a sample of members from the research population, with the objective of reducing mistakes and controlling extraneous variables. In this process, teacher-researcher observed that some students reacted with visible discomfort, finding it difficult to cope simultaneously with listening and writing; this was made evident by numerous requests for repetitions. The teacher-researcher also found it necessary to adjust the pace of delivery to a level with which the participants felt comfortable. At times, students had difficulty distinguishing between certain phonemes, such as the difference between diphthongs /ei/ (as in say/'seI/) and /ai/ (as in bike/'bark/). After adjustments based on the piloting experience were made, it was thereafter observed that the students developed a more natural attitude towards dictations during the actual data collection process. This helped strengthen the validity of the dictation instruments by attenuating the possible effects of anxiety. 


\subsection{Conclusion}

To conclude, an experimental design was an appropriate one because it permitted to test the nature of the subject matter, spelling, following a cause and effect relationship after the treatment (direct and indirect WCF) was applied over spelling. Dictations were the main data collection instrument to test the efficacy of direct and indirect WCF on spelling accuracy as dictations made possible for the teacher-researcher to focus on the spelling factor and control extraneous variables. Thus, the teacher-researcher used the student artifacts produced from the dictation processes to gather data which permitted the teacher-researcher to focus on a single error category, spelling, in order to examine whether it was affected by the treatment (WCF). This is the reason an experimental approach was appropriate, as this kind of research design makes it possible to establish relationships, such as this study sought to examine between the treatment (WCF) and the subject matter under scrutiny (spelling). 


\section{Chapter 4: Pedagogical Intervention and Implementation}

\subsection{Introduction}

As mentioned, the instructional design of this experimental study was set up to portray in a "clean" way the effect of direct and indirect WCF over spelling mistakes. The cause and effect relationship established in this study was quantified (spelling errors) thus, accurate. This is a great value of this experimental design, as its precise nature make possible exact outcomes that are calculable; thus, show in a clear way a cause and effect relationship.

Moreover, this chapter discusses the teacher-researcher's stances on language, language learning, and curriculum with the purpose of giving the reader elements to understand the teacher-researcher's choices and actions. In particular, this study conceives of language principally as a means of communication, in especially with regards to how English language has become one of the most common means of communication around the world. This has led to the need for ways to more effectively teach and learn English everywhere.

\subsubsection{Vision of language}

Communication in a broad sense is information transmitted to generate meaning within and across various contexts. It is one of those activities so rooted in human life that often its occurrence and importance is overlooked Littlejohn and Foss (2011). However, communication is central to human life because every aspect of our everyday life is affected by communication (Littlejohn \& Foss, 2011). As human beings, we can communicate with each other to express knowledge, beliefs, opinions, wishes, threats, commands, thanks, promises, feelings, and more; only the imagination sets the limit.

Communication can take place through non-linguistic or linguistic means. Non-linguistic communication uses representational messages in which each particular signal is associated with 
specific signaler emotions, intentions, or external referents (Owren \& Barochorowski, 2003). It is accomplished through body gestures, such as a smile (to express amusement, pleasure, or approval), a clenched fist (to express determination, anger, or threat), a raised eyebrow (to express surprise or disapproval), or it can be accomplished through visualization (graphs, charts, maps, logos). With body gestures, each particular expression or gesture is considered linked to a particular emotion — see, for example, Kelter and Ekman (2000) and Keltner, Ekman, Gonzaga, and Beer (2003) — and are also a source of meaningful interaction between individuals (Gregory \& Carroll, 1978).

In contrast, linguistic communication is achieved through language, a system of signs or symbols governed by grammatical rules used to create and convey meaning. In conveying meaning, language can likewise be understood as a means of establishing and maintaining human relationships Torto (2014). Although the most familiar signs/symbols used to form human language are probably those of spoken sounds, other linguistic signs/symbols can be used, such as those produced through body gestures (i.e. sign language) and those produced graphically, such as through writing. Written language can itself take varying approaches to conveying meaning; for example, in logographic writing a given glyph represents an entire word or morpheme, while in alphabetic writing particular glyphs represent sounds in the corresponding spoken language. In the present study, somewhat distinct (but related and not dissimilar) alphabetic writing systems are used for the written versions of both the participants' L1 and L2.

\subsubsection{Vision of learning}

The results from Colombian students in the 2015 PISA (Program for International Student Assessment) exams suggest that Colombia needs to improve its educational system if its 
citizens are to develop the necessary skills and abilities needed to deal with twenty-first century demands (OECD 2016, 2016) (Organization for Economic Cooperation and Development). Colombia's results in the three areas tested-Science, Reading, and Math-were all below the average. PISA exams are designed to test how well individuals can apply their knowledge to solve unfamiliar real-life problems inside and outside the classroom, founded on the understanding that modern societies compensate individuals not for what they know but for how well they use their knowledge to develop new proposals that address and solve society's problems. Hence, contemporary societies require an innovative approach to literacy that develops students' capacities to extrapolate from what they have learned, to analyze and reason, as they seek to interpret and solve problems in different situations (OECD 2016, 2016). Consequently, corrective actions need to be taken to adapt the Colombian educational system to twenty-first century demands. Beare and Slaughter (1993) argue that most planning, writing, and public debate about education assumes a static world-view in which existing educational stakeholders and curricula are treated as if they have been, are, and will continue to be the key and long-lasting features of an educational view that opposes what society needs and rewards. This indeed seems to be the case of the Colombian educational system.

The teacher-researcher's vision of learning is situated along the constructivist paradigm, in which it is understood that students integrate prior knowledge with unfamiliar information to create new learning. This approach helps develop life-long learning, as it permits students to pursue their personal interests and use and develop their own abilities by building on prior knowledge and experience (Richardson, 2003). The constructivist approach is relevant to the Colombian educational system's needs, which require that the center of learning shift from the teacher to the student so as to let students be creative in constructing knowledge based on their 
own experience, context, information, needs, and lacks. With respect to this, Hein (1991) argues that the main idea embedded in constructivism is that people learn by coming up with new ideas_-which is essentially what learning entails. Students need to be empowered to create and construct knowledge, and the constructivist approach develops such empowerment in students by encouraging them to look into their own skills and abilities — and, thereby, develop them. Schuh (2003) argues that constructivist education is based on students' effort rather than instructors' work because constructivism emphasizes a student-centered mode of learning, as opposed to "traditional" instructor-centered education. Constructivists view learning as occurring when an individual examines, interprets, codes, and decodes concepts and ideas, implying that learning is not simply a matter of being exposed to new information, but an active and meaningful process based on an individual's own interpretation of reality whereby they come up with creative and new ideas to respond to their own and society's needs (Pagan, 2006). Moss (2003) argues that constructivist modes of teaching and learning are supported by programs that train instructors to encourage students to discover their own principles with the knowledge they already possess as a way to embrace and acquire knowledge.

Following the above-mentioned line of thought, it can be argued that feedback should empower students in the construction of knowledge by increasing their self-efficacy and motivation (Brookhart, Moss, \& Long, 2008). After the teacher initially points out a mistake, the student is left with awareness of the mistake and the knowledge that it should be corrected. This is empowering because it promotes strengthening weaknesses pointed out through feedback, which can also be used to give the student a tool (knowledge of the correct form) that further empowers them by enhancing their capacities for written communication, a necessary and important element in contemporary Western processes for the construction of knowledge. 


\subsubsection{Vision of curriculum}

Curriculum development processes are crucial to helping educational institutions achieve their goals (Richards, 2001). Richards defines a curriculum as all those activities in which students participate under the school's patronage. Designing a curriculum requires multiple considerations like a needs analysis, situational analysis, planning, learning outcomes, course organization, selecting and preparing teaching materials, and evaluation Richards (2001). Furthermore, to design a curriculum for a given student or group of students, it is important to consider the different perspectives of the various stakeholders that affect or are affected by decisions pertaining to curriculum design, such as policy makers, professional advisors, course designers, teachers, sponsors, and learners. Wiggins and Mc Tighe (2006) observe that a curriculum is normally put together in accordance with external standards and local goals, while Reppen (2010) notes that ESL/EFL professionals, like teachers and testing specialists, continuously make decisions about language curricula, including which features and vocabulary to teach and test. However, to design an accurate curriculum, it is important to consider the reasons why students want to learn the curricular content—in this case, a foreign language such as English. In other words, it is important to determine the motivation behind students' language learning and, in theory, this should be part of curricular design. Trim (1978) argues that curriculum designers should set goals according to the communicative needs of learners in order to determine what knowledge and skills will prepare the learners to meet their learning needs and objectives.

A formal language program that includes a testing and evaluation system should be developed in accordance with learners' needs so that learners acquire the necessary language skills and abilities to communicate (Trim, 1978). However, the teacher-researcher has observed 
that, in the milieu in which she has taught, much more weight is usually given to what decisionmaking stakeholders think is appropriate than to learners' views. Moreover, the teacherresearcher has noticed that this usually results in a gap between what the decision-making stakeholders think is best with respect to what and how a particular language should be acquired and what students really want and need. Long (2005) argues that it is vital to be aware of students' needs when designing a course and lesson's objectives. Likewise, Tarone and Yule (1989) suggest that performing a needs analysis can help reduce the gap between teachers' and students' expectations, as it can inform instructors about students' needs, which in turn supports appropriate decision-making in terms of pedagogy, content, and assessment.

Furthermore, curricula based on needs analyses can help keep students engaged, as it may better address their language needs (Tarone \& Yule, 1989).

\subsection{Instructional design}

As discussed in section 3.2.1, this study followed an experimental action research design in which WCF was applied to three groups in two populations with the purpose of examining possible effects on the subjects' performance. Tables 1 and 2 show that in Population 1 subjects P1G1 and subjects P1G2 received the treatment of direct and indirect WCF. As mentioned in section 2.3.2, direct WCF was given by underlining the linguistic error and then the correct linguistic form or structure was provided by the teacher researcher. Indirect WCF was called to the attention of the learner by highlighting it, but the correct form was not provided. The participants in Population 1, P1G1 and P1G2, only met for language instruction twice a week; for that reason, the treatment was applied with twenty-day intervals, as the few hours the classes met (section 3.2.2), could not be dedicated solely to research purposes, as the teacher-researcher 
also needed to advance with other aspects of the language-course curriculum. With respect to Population 2, the dense curriculum of their language course (the large quantity of material to be covered each week, plus the teacher-researcher's work load in correcting students' work) likewise did not permit a shorter time span in between treatment applications.

\subsubsection{Lesson planning}

The lesson plan used in this study's pedagogical intervention was adapted from a model provided by Joan Rubin (personal communication, May 12, 2012). For a complete example of a lesson plan as used in this study, see Appendix E. This lesson plan model was designed to support development of student consciousness with respect to language errors by focusing on one error category (Appendix E, Step 1) spelling, (Kidd, 1992), which made provision of WCF more manageable for the teacher-researcher (see 3.3.1.1).

The purpose was to determine whether WCF was effective in treating spelling mistakes. In this respect, Lee (2008) argues that corrective feedback should be provided for a specific or a limited number of grammatical structures and errors/mistakes. Focusing on only a few errors/mistakes can be more effective than attempting to address all errors, because this can become overwhelming for both student and teacher. Moreover, Ellis (2008) argues that focused (as compared to unfocused) feedback, better helps learners direct their attention to specific error categories (Appendix E, Step 1). This likewise helps make tasks more manageable and meaningful for both teachers and students (Evans et al., 2010). In this study, it helped the teacher-researcher draw conclusions based only on the feedback treatment (see section 3.3.1.1). Evans, Hartshorn, McCollum, and Wolfersberger (2010) argue that it is sensible to identify what should be corrected, as this makes it easier to determine the most effective way for students to process and subsequently learn from feedback. 


\subsubsection{Implementation}

The teacher-researcher carried out the dictation activities by reading the texts aloud in intelligible bursts (Appendix E, Step 4). Each burst dictated was three to five words and a gap in between bursts of five to approximately 10 seconds, based on the length of the burst. Tables 1 and 2 below show information about the kind of feedback provided (Treatment), the number of subjects in each sample group (Sample), the number of words in each dictation (Words), the particular dictation in the process (Occasion) such as $1^{\text {st }}$ dictation, $2^{\text {nd }}$ dictation, and the $3^{\text {rd }}$ dictation which was the last dictation, and finally the interval which indicates the time span that elapsed between each dictation process. The final dictation in Table 1 and Table 2 is the no treatment under the heading Treatment because they were the final dictations given to Population 1 and Population 2 where the errors were counted but no WCF treatment was applied.

For Populations P1G1, P1G2, and P1G3 texts for the dictations were sourced from Eales, Wilson, Clare, Oaks (2011) book (see Appendix C). For Population P2G1, P2G2, and P2G3 Foresman's (2007) book was the source of texts for the dictations (see Appendix C).

Populations, P1G1 and P1G2 both received direct and indirect WCF feedback, while the control group P1G3, did not receive any feedback. PIG1 received direct WCF feedback on the first dictation and indirect WCF feedback on the second dictation. P1G2 received indirect WCF in the first dictation and direct WCF on the second dictation (Table 1). In Population 2, groups P2G1 and P2G2 both received the same kind of feedback on the two dictations that feedback was provided; P2G1 only received direct feedback on dictation 1 and dictation 2, and P2G2 only received indirect feedback on dictation 1 and dictation 2 . The control group P2G3 did not receive any feedback (see Table 2). Finally, results of both Populations were calculated based on the number of misspelled words from each artifact. 
Table 1

Treatment application for Population 1.

\begin{tabular}{|c|c|c|c|c|c|}
\hline Treatment & Group & Sample & Words & Occasion & Interval \\
\hline Direct & G1 & 10 & 163 & $1^{\text {st }}$ & 0 days \\
\hline Indirect & $\mathrm{G} 2$ & 10 & 163 & $1^{\mathrm{st}}$ & 0 days \\
\hline Indirect & G1 & 10 & 150 & $2^{\text {nd }}$ & 20 days \\
\hline Direct & $\mathrm{G} 2$ & 10 & 150 & $2^{\text {nd }}$ & 20 days \\
\hline No treatment & G1 & 10 & 145 & $3^{\text {rd }}$ & 20 days \\
\hline No treatment & G2 & 10 & 145 & $3^{\text {rd }}$ & 20 days \\
\hline
\end{tabular}

Table 2

Treatment application for Population 2.

\begin{tabular}{|c|c|c|c|c|c|}
\hline Treatment & Group & Sample & Words & Occasion & Interval \\
\hline Direct & $\mathrm{G} 2$ & 10 & 119 & $1^{\mathrm{st}}$ & 0 days \\
\hline Indirect & G1 & 8 & 119 & $1^{\text {st }}$ & 0 days \\
\hline Direct & $\mathrm{G} 2$ & 10 & 105 & $2^{\text {nd }}$ & 20 days \\
\hline Indirect & G1 & 8 & 105 & $2^{\text {nd }}$ & 20 days \\
\hline No treatment & G1 & 10 & 115 & $3^{\text {rd }}$ & 20 days \\
\hline No treatment & $\mathrm{G} 2$ & 8 & 115 & $3^{\text {rd }}$ & 20 days \\
\hline No Feedback & G3 & 10 & 146 & One time only & 20 days \\
\hline
\end{tabular}




\subsection{Conclusion}

The importance of the English language around the world has made its learning and teaching a topic of study and analysis whereby stakeholders in the field attempt to find more and better ways to teach and learn this language effectively. The awareness created in the learner about the spelling error once the spelling error was pointed out through the applications of the direct and indirect WCF treatment was considered empowering by the teacher researcher as it gave learners control over their spelling. Data resulting after the application of the treatment of direct and indirect WCF revealed important insights like that it suggested that the way feedback has been applied thus far may need to be revised. The data and its results after running it through a one-way ANOVA statistical test are depicted in Chapter 5. 


\section{Chapter 5: Results and Data Analysis}

\section{$5.1 \quad$ Introduction}

The data, spelling errors, collected from the artifacts produced after carrying out three dictation procedures to three groups $(\mathrm{G} 1, \mathrm{G} 2, \mathrm{G} 3)$ within two populations $(\mathrm{P} 1, \mathrm{P} 2)$ (section 3.3.1.1), was run through the one-way ANOVA statistical test in order compare results (quantity of spelling errors) among the three groups within the two populations after the application of the treatment of direct and indirect WCF. The main results showed lack of statistical significance within groups in both Populations P1 and P2. Other results produced information that illuminated areas pertaining to the nature of the English language. Furthermore, the results pointed to the need to make a close examination to the way feedback has been carried out. The teacherresearcher's outcomes, plus the inconclusive results attributed to WCF throughout the literature, informed the teacher-researcher that the way feedback has been given so far, needed to be reevaluated.

\subsection{Data management procedures}

The data was gathered by means of three dictations (see 3.3.1.1 and 4.2.2) that were performed to each group that participated in the study (see 3.2.2). After each dictation, the artifacts were collected and corrected by applying the treatment of direct and indirect WCF. As portrayed in Tables 1 and 2 in section 4.1.5, Populations P1G1 received indirect and direct WCF, on dictations 1 and 2. Populations $\mathrm{P} 2 \mathrm{G} 1$ and $\mathrm{P} 2 \mathrm{G} 2$ received the same kind of $\mathrm{WCF}$ on the two dictations that feedback was provided; P2G1 only received direct feedback and P2G2 only received indirect feedback. The relevant data collected from each artifact was the number of misspelled words from each subject. The teacher-researcher recorded this data systematically in digital spreadsheets, providing a record of each of the subject's performance and making it 
possible to retrieve and analyze the information, as well as to make it easier to visualize. The teacher-researcher verified this data by cross-checking it against the original artifacts. Miles and Huberman (1994), consider data verification a critical step for reaching effective conclusions.

\subsubsection{Validation}

According to Brown (2005), a test has validity when it measures what it claims to be measuring. With respect to this study, for the results to be considered valid, it was necessary to ensure that they were a direct consequence of the feedback treatment's impact. Kvale (1989) argues that the concept of validity relates to the extent to which any given method genuinely investigates what it was set to investigate. In the present study, the teacher-researcher sought to ensure validity by controlling as much as possible the extraneous variables that could have had an influence on the results, such as the pace at which the dictations were delivered, by choosing appropriate dictations for the students' level, by delivering the bursts with appropriate intervals in between them, and by controlling external factors such as noise, by closing doors and windows.

\subsubsection{Data analysis methodology}

\subsubsection{Dependent and independent variables}

The dependent variables were the resulting scores of the participants after the application of the WCF treatment; and the independent variables were the groups P1G1, P1G2, P2G1, and P2G2, which participated in the experiment and the direct and indirect WCF. The data, misspelled words (see section 5.2), was then processed in order to draw conclusions from it (Nunan \& Bailey, 2009). The value of this quantitative approach was that it was possible to establish a cause and effect relationship of the treatment and outcome. 
Measures of central tendency and dispersion were used. The measure of central tendency used was the means, which describes how scores in a given data set cluster Bailey (1998), and the measures of dispersion used were the variance and standard deviation, which provide information about how spread out the scores are in a given data set (M. Bailey, 1998). The variance captures the collective amount of differences in any given set of scores and the standard deviation is the square root of the variance (M. Bailey, 1998). In order to capture the impact of the direct and indirect WCF feedback, the resulting data after the applications of the Treatment amongst the groups (G1, G2, G3) within the two Populations (P1 and P2) was compared by running the data through a one-way ANOVA statistical test because its design permits comparisons between three or more groups. Appendix F provides the data used in the one way-ANOVA statistical test (Tables 4-17).

\subsubsection{One-Way ANOVA}

The one-way ANOVA statistical test (Gould \& Colleen, 2013) was used to determine whether there was any significant statistical difference in the mean numbers of errors produced by each of the groups that participated in the study in order to determine how each group might have been different from the others at each stage of the feedback treatment. In this experiment, there was a null and an alternate hypothesis for treatment, population, and extraneous elements. A null hypothesis is what is set out to be proven by researchers in an experimental study as true or false. The alternate hypothesis looks at whether there is enough change to be able to reject the null hypothesis. Thus, the interest is on the acceptance or rejection of the null hypothesis (Gould \& Colleen, 2013). The one-way ANOVA test was used because it compared the three group means, which in this experiment were the means of population, treatment, and interactions (extraneous element) after applying two types of feedback treatment, direct and indirect WCF. In 
other words, the one-way ANOVA test permitted analysis of the variability in data in order to infer the inequality among the different population means. Moreover, this test involves simultaneously the measures of central tendency (mean), measures of dispersion (variance and standard deviation), and the level of statistical significance, or p-value. The p-value, established at 5\% (0.05) (Gould \& Colleen, 2013) is a reference point. In this experiment it is used to determine whether those means are significantly different from each other. If the p-value is greater than 0.05 , the results are interpreted as not having a significant statistical difference. If the p-value is below 0.05 , this means that there is a statistically significant difference.

\subsection{One-Way ANOVA work hypotheses.}

The null and alternate hypothesis were represented as: $\mathrm{H} 0$ for the null hypothesis and H1for the alternate hypothesis. Population is represented with the number 1, treatment with the number 2, and interactions (extraneous elements) with the number 3. Consequently, the null hypotheses for population, treatment, and interactions are represented as: populations (H01), treatment ( $\mathrm{H} 02)$ and interactions is (H03), and the alternate hypotheses for population is ( $\mathrm{H} 11)$, for treatment is (H12) and for interactions is (H13).

\subsection{Results}

A null and an alternate hypothesis were established. The resulting p-value from the ANOVA test determined the significance of the statistical difference between group means in the three aspects that were compared; populations, treatments, and interactions. The following were the null and alternate hypotheses:

- $\quad$ Null hypothesis H01: There does not exist difference in the mean percentage of errors in between populations. 
- $\quad$ Alternate hypothesis H11: There exists a difference in the mean percentage of errors in between populations.

- $\quad$ Null hypothesis H02: There does not exist a difference in the mean percentage of errors in between treatments.

- $\quad$ Alternate hypothesis H12: There exists a difference in the mean percentage of errors in between treatments.

- $\quad$ Null hypothesis H 03: There does not exist interaction of extraneous elements.

- $\quad$ Alternate hypothesis H13: There exists interaction of extraneous elements.

To determine whether any of the differences between means were statistically significant, the resulting p-value was compared to its significance level of 0.05 .

\subsubsection{Application of the one-way ANOVA statistical test}

The raw data considered was the total numbers of misspelled words from each student artifact. Measures of dispersion such as variance and standard deviation and measures of central tendency such as, the mean, were considered for each group within both Populations 1 and 2 (see Appendix F, Tables 4-17). The resulting scores from tables 4-17 were then consolidated in table 15 (see Appendix F, table 18). One-way ANOVA statistical test was run over the data. Then the statistical significance of each of the factors (p-values) was analyzed. Appendix G shows that the p-value for Population is 0.4911 , for Treatment is 0.1302 , and for Interactions (AB) 0.6272. Since no p-values are less than 0.05 , none of the factors or interaction are statistically significant. This validates the null hypotheses; hence, the alternate hypotheses are ruled out. This means that the treatment did not cause any major changes among the groups. 


\subsubsection{Results on patterns of orthographical errors}

This study also presents other results such as the emergence of patterns in the English language spelling that came to the attention of the teacher researcher as problematic for her students (see Table 3). 
Table 3.

Spelling Errors and Patterns.

\begin{tabular}{|c|c|c|}
\hline English Spelling & English Phonemic Representation & Erroneous Participant Spelling \\
\hline Stone & /stoun/ & $\langle$ stoun $\rangle$ \\
\hline No & /nov/ & $\langle$ mow $\rangle$ \\
\hline Most & /'moust/ & $\langle$ moust $\rangle$ \\
\hline Hope & /houp/ & $\langle j o b\rangle$ \\
\hline Make & /merk/ & $\langle$ meit $\rangle$ \\
\hline Made & /meId/ & $\langle$ maid $\rangle$ \\
\hline They & /ðё/ & $\langle$ day $\rangle$ \\
\hline Word & /w3:d/ & $\langle$ wor $\rangle$ \\
\hline The & /ði/ & $\langle\mathrm{de}\rangle$ \\
\hline Eventually & /ı.'ven.tfu.li/ & 〈eventualy〉 \\
\hline Knows & /novz/ & $\langle$ nows $\rangle$ \\
\hline Talk & /tok/ & $\langle$ tok $\rangle$ \\
\hline Island & /'arlond/ & $\langle$ ilan $\rangle$ \\
\hline Statues & /stætJu:z/ & $\begin{array}{l}\langle\text { status }\rangle \\
\langle\text { statius }\rangle\end{array}$ \\
\hline Keеp & /ki:p/ & $\langle$ kip $\rangle$ \\
\hline Eat & /it/ & $\langle i t\rangle$ \\
\hline
\end{tabular}


This provided a richer view into the causes of misspelled words by this study's populations and a source of a linguistic analysis of English spelling by native Spanish speakers. The patterns that emerged were:

a) Misspelling due to grapheme/phoneme confusion occurred when a learner transcribed an English phoneme using a grapheme appropriate to Spanish orthography. For example, English hope /hoop/ was transcribed by the learner as $\langle\mathrm{job}\rangle$, as though the phoneme $/ \mathrm{h} / \mathrm{is}$ typically represented by $\langle\mathrm{h}\rangle$ in English orthography, it is in contrast typically represented by $\langle j\rangle$ in Spanish orthography. Other examples of grapheme/phoneme confusions of this nature included: the English word make /merk/, written as $\langle$ meit $\rangle$, where the /k/ was perceived by the learner as /t/ and written $\langle\mathrm{t}\rangle$; the English word the /ðə/ written as $\langle\mathrm{de}\rangle$, perhaps because Spanish /d/, typically written $\langle\mathrm{d}\rangle$, is often phonetically realized as /ठָ/; perhaps for the same reason, the word they/ðeI/ was transcribed as $\langle$ day $\rangle$, and the word worth /w3.1 $\theta /$ was transcribed as $\langle$ word $\rangle$.

b) The diphthong /ov/ in stone /stoun/ was frequently transcribed as $\langle\mathrm{ou}\rangle$ : $\langle$ stoun $\rangle$. Similarly, no /nov/ was transcribed $\langle$ now $\rangle$; most /'moust/ as $\langle$ moust $\rangle$; made /meIdd/ as $\langle$ maid $\rangle$; and make /merk/as 〈meit〉.

c) Many instances where English orthography uses two graphemes in sequence, either the same or different, to represent a single phoneme, were transcribed by a single grapheme;

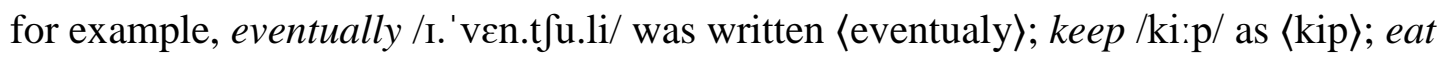
/it/as $\langle i t\rangle$.

d) Many "silent" letters in English orthography were omitted; for example, island /'arlənd/

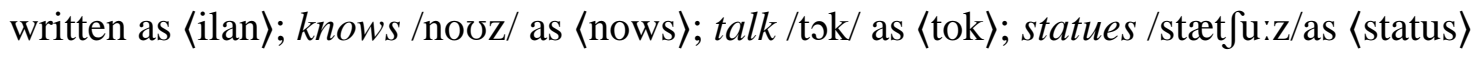
hope /houp/ as 〈job〉. 
As evidenced above, the most frequent pattern involved English phonemes not represented in Spanish phonology, whereby students tended to draw on their Spanish schemata to transcribe them. Along these same lines, Cronnell (1985) in his study involving Mexican-American learners and Raynolds and Uhry (2010) in his study of Spanish-English bilingual learners also found in their respective studies that the word funny /'f $\wedge$ ni/ was written as $\langle$ fonny $\rangle$ and the word wish /wI / was written as 〈wich〉.

\subsection{Conclusion}

The results show that there were no significant statistical differences in the L2 English spelling performance between the groups of both populations after the application of the treatment. This indicates there was no feedback effect; hence, no superiority of one type of feedback over another. The p-values of 0.4911 for population, 0.1302 for treatment, and 0.6272 for interactions are greater than 0.05 ; thus, there were no significant statistical differences, and therefore the null hypothesis for Treatment, Population, and Interaction was validated. The consequences of these results are discussed in Chapter 6 in light of the significance of the type of feedback given for the type of error committed. Moreover, as the results presented in section 5.3.2 suggest, students had greater difficulties with certain phonemes, suggesting that students' pre-existing schemata, such as their knowledge of their L1, may have had an influence on many of the kinds of mistakes they made when trying to spell words from the L2. These results suggest that there might be a problem with the type of feedback given for form-focused mistakes such as spelling; that is, that the type of feedback given might have not been the most appropriate type for treating spelling errors. 


\section{Chapter 6: Conclusions and Pedagogical Implications}

\subsection{Introduction}

The purpose of SLA is to comprehend the deep-rooted process that goes on in the learner's mind on their way to acquiring any given linguistic feature. For this reason, it is important to find ways of giving feedback that are effective (Truscott, 1999). Overtime, little attention has been given to testing WCF's efficacy (D. Ferris, 2004).

Since Truscott's call for the abandonment of error correction (Truscott, 1999), many questions have remained open related to how to provide feedback (H. D. Brown, 2001). Up to now, an increasing number of studies have been investigating the relative effectiveness of varying types of feedback (Ghandi \& Maghsoudi, 2014), but there is still controversy in the field as to which type of feedback would help L2 English learners. Yet the results remain inconclusive. This leads the researcher of this study to conclude that perhaps the focus of the feedback given so far is not the correct one and, for that reason, studies have produced conflicting results. This section examines and analyses the role that corrective feedback has had so far, and the reasons for the conflicting results.

\subsection{Comparison of results with previous studies' results}

The mixed findings in the field of WCF have led to multiple conclusions, some of them acknowledging WCF as ineffective while others recognize its effectiveness. In addition to Truscott's results claiming that feedback is ineffective (2007), already mentioned in this study, other studies, such as those of Krashen (1984) and Samke (1984), have also claimed that that error correction should be abandoned because of its ineffectiveness in the long run. On the other hand, studies such as those of Bitchener, Young, and Cameron (2005), Ferris (2006), Russel and Spada (2006), Sheen (2007), Bitchener (2008), Ellis, Loewen, and Erlam (2006) and Ellis 
(2008), have claimed that WCF improves writing accuracy in limited contexts. Moreover, studies such as that of Lalande (1982) have found that WCF leads to lower error rates. Furthermore, results from other studies have shown other aspects of feedback, such as the fact that the kind of feedback given, and its level of explicitness should depend on a range of contextual factors, like the type of error, the nature of the writing task, and the student's proficiency level (Storch, 2010; C. Van Beuninge, 2010). Other results, such as those of Santos, Lopez-Serrano, and Manchon (2010), show that the effects of WCF can vary significantly even amongst participants receiving the same kind of WCF in the same experiment. This array of results has left teachers puzzled over how to interpret such conflicting findings and how to identify what specific steps they could take to help their students write more accurately.

This study's results, indicating there was no significant impact in spelling accurateness after the application of either of the treatments designed, seem to confirm the findings of Krashen (1984), Semke (1984), and Truscott (1996, 2007). However, such an assumption must be looked at with caution for several reasons. Firstly, upon observation and analysis of the artifacts, the researcher noticed that the specific difficulties Spanish-speaking learners of English have with certain phonemes (section 5.4) may have contributed to the ineffectiveness of the explicit direct and indirect feedback treatment upon their spelling errors. This is because explicit direct and indirect feedback treats the error per se; it treats the form, but not the cause, of the error. This means it addresses the problem of spelling from the surface but does not address any underlying factors that might be contributing to a mistake or why it is made. Mistakes could be caused for different reasons. As stated by Storch (2010) and C. Van Beuninge (2010), factors like the nature of the writing task, and students' proficiency level could have affected the results. However, they were not the focus of this study therefore conclusions based on them cannot be 
made without further research to support them. Here, the evidence points to the likelihood that one factor that could have been influencing the spelling mistakes displayed in the results from the present study could have been the transfer of a learned spelling schemata — an existing paradigm of likely phoneme-grapheme correspondences - appropriate to the participants' L1 to their L2. Such a possibility may be exemplified in, for example, the participants' frequent representation of English the (/ði/ or /ðə/) as $\langle\mathrm{de}\rangle$. Additionally, another reason associated could be their lack of familiarity with certain English phonemes, including many vowels and diphthongs that do not exist in Spanish, or at the very least their native variety of Spanish (for example, /ə/ and /ov/). Consequently, it is interpreted that the kind of treatment that was applied in the present study had no measurable effect because it tried to "cure" a "sickness" with the "wrong medicine". In order to apply the "correct medicine", one has to know the cause of the "disease" (i.e. mistake) per se in order to find the best and most effective treatment for it.

\subsection{Significance of the results}

This study's results could lead one to conclusions similar to those of previous studies, mentioned in section 6.2, that likewise claimed no apparent effect was attributable to WCF and thus, that feedback is essentially useless. However, as pointed out by Evans, Hartshorn, McCollum, and Wolfersberger (2010), it is difficult to imagine or think about anything learned without feedback. The lack of a significant difference between the application of direct and indirect WCF treatment to spelling mistakes found in the present study is also apparent in other studies, such as those of Rob, Ross, and Shorted (1986) and Semke (1984). Evans, Hartson, McCollum, and Wolfersberger (2010) argue that such a lack of significant difference is due to uncontrollable variables associated with learners, methodologies, and situations. The researcher of this study would, however, add to this list the kind of feedback given to the type of 
error/mistake - though noting that such a variable could be better controlled if sufficient and appropriate understandings were available about the underlying causes of mistakes. Furthermore, the literature on WCF shows that studies depicting conflicting results (as discussed in section 6.2) or no results are common, on which issue Guennette (2007) observes:

Rather than interpret the conflicting results as a demonstration of the effectiveness or ineffectiveness of corrective feedback on form, I suggest that findings can be attributed to the research design and methodology, as well as to the presence of external variables that were beyond the control and vigilance of the researcher. (p. 40)

The researcher of the present study concurs, but also considers there to be other, less evident factors that may have very important influences on the results of this and other similar studies. Indeed, in the present study, analysis of the kinds of mistakes (section 5.4) made by participants—particularly the patterns in their spelling errors, especially with unfamiliar phonemes-leads the researcher to conclude that the participants were transferring their L1 knowledge of Spanish orthography to their L2 representation of written English. Moreover, analysis of the data suggests that the kind of feedback given for spelling mistakes (form-focused) might at least partially explain the lack of measurable impact of the treatment on subsequent spelling performance, because the purpose of the treatment was only to treat the existence of the mistake and not the cause of the mistake. This leads the researcher to understand that the real problem requiring treatment is indeed the underlying cause of the mistake-about which the data is suggestive, though more research would be needed in order to confirm that this is happening and, indeed, to better understand the mechanisms through which it is performed. Nevertheless, the preliminary results from this study suggest that a feedback focused on the relation between leaner's L1 and L2 might be more effective than other types (e.g. purely form-focused) feedback. 
This raises questions about to the kinds of feedback used in previous studies, such as whether the researchers considered the underlying causes of errors in given participants populations to devise feedback keyed to those causes - or whether research on feedback has generally tended to surface representations of given errors/mistakes. It may well be that students could make better use of certain kinds of feedback than on others.

With regard to feedback on spelling errors, it seems that more in-depth analysis of the likely reasons for the occurrence of particular errors would provide critical information about what kind of feedback might be needed to address those reasons — and both reasons and responses are most likely dependent on L1-L2 relationships. However, the very emphasis in many contemporary language-teaching environments on consciously avoiding any use of (or reference to) the learners' L1, whether enshrined as a fundamental methodological principle or a practical necessity (because a teacher/researcher does not share learners' L1, or the learners a mixed group with various L1s) may well have discouraged such considerations. Nevertheless, greater appreciation of L1-L2 relationships could lead to insights that could be extrapolated to help treat various types of learner error/mistakes (not only spelling mistakes). Such approaches could also enliven research on feedback with, not necessarily new forms of feedback, but better pedagogical strategies for deciding on how, and on what, to apply it.

To conclude, the researcher's analysis of the patterns of mistakes made by participants in the present study points out to the existence of underlying reasons for the mistakes ingrained in the learners' pre-existing spelling schemata for Spanish orthography and that, therefore, the explicit direct and indirect form-focused feedback applied was found to be ineffective because it only treated (was only designed to treat) the errors superficially; in other words, the treatment focused on correcting the form but not the cause of mistakes. 


\subsection{Further research}

There has been little research on how the presence of a given L1 orthographical schemata affects acquisition of L1 spelling rules - and, thus, likewise little research on how to design feedback that accounts for such processes. More research on such matters is needed; for example, frequency analysis studies of erroneous learner spelling patterns to provide better insights on what kind of error treatment could be more effective. Frequency analysis reveals the process underlying the acquisition of language features (Ellis \& Barkhuizen, 2005). Such frequency analyses could address the stages of development and sequences of acquisition through which learners go as they acquire any given linguistic feature, making it possible to study how they acquire knowledge of particular forms (as is the case for spelling). Other advantages of this kind of approach would include that: a) learners are examined in their own right, and b) the gradual development of learners' interlanguage would be revealed over time. With respect to spelling, after such frequency analyses, researchers should have better understandings of the evolutions of orthographic phoneme-grapheme relationships in a given spelling schemata and, in that way, be better able to address the topic of acquisition as a result of cause and effect relationships. The nature of frequency analysis requires a longitudinal study since it is done over a considerable period of time; for example, studies by Bitchener (2008) and Bitchener and Knoch (2008a, 2008b, 2009) have suggested that WCF can help improve accuracy in the writing of new texts over time. However, most studies on WCF so far have focused on the impact of a given treatment on an error/mistake in the short term but not on an analysis of learners' progression over time until the learner finally acquires the ability to produce correctly spelled forms. This would require a vertical analysis of given mistakes to permit a view on different stages of development as the learner moves toward acquisition of the target (or correct) 
form. A frequency analysis determines the stages of development a learner goes by cataloguing the various linguistic devices used over time, revealing the gradual development of the learner's interlanguage (Ellis \& Barkhuizen, 2005). However, although a frequency analysis could describe the process underlying acquisition of the correct spelling, it would not explain this process.

Accordingly, another area in which further research is needed concerns the relation between a learner's L1 and L2. There are some languages with sufficiently close relationships that it is certainly necessary to consider how schemata from a learner's L1 might affect competences with L2. This could readily be the case with, as considered in the present study, L1 Spanish-users attempting to acquire L2 English orthographical competences, though the relationship would clearly be quite different in other cases; for example, one would expect less L1 orthographical influence in the case of Mandarin-speakers studying English spelling. An analysis of such situations would reveal other processes underlying a given learner's acquisition of the L2 target language, as patterns of acquisition would probably differ considerably depending on the schemata particular to a given L1 linguistic background. The kind of schemata that a Spanish-speaking learner brings to the learning process might be expected to be quite different from the kind of schemata that a Mandarin-speaking learner brings. Such considerations would offer fresh insights concerning what goes on in learners' minds during the process of language acquisition.

\subsection{Limitations and pedagogical implications}

The results of this study suggest that there are other. Possibly more effective, ways to approach feedback. These results indicate that the patterns of learner mistakes may be related to the causes of those mistake. This understanding raises the question of whether the results would 
have been different if the feedback had addressed the cause instead of the symptom of the error/mistake. Consequently, questions remain about what the focus feedback should have other than just existence or form of the mistake so as to promote better learning. Possibly there should be a focus on the individual per se, as for levels of cognition and motivation. There would nevertheless remain a need to better understand the causes of learner error/mistakes (which could vary widely, depending on the context and the linguistic/communicative competence at issue) so as to design better ways to provide feedback. This would have pedagogical implications, as teachers would have to adapt their ways of providing feedback to consider the cause of the mistake and treat it appropriately.

\subsection{Conclusion}

Research on the role of feedback in supporting learners' L2 writing competences reveals that there are no simple answers. Questions that continue deserving special attention concern the kinds of errors that merit feedback, how and when to give such feedback, and the possible benefits of such feedback. Although the present study sought to address such questions directly, the results were inconclusive with regards to the simple efficacy of feedback, though they do highlight problems with much previous work on this topic: namely, that few studies have considered the causes of errors, particularly with regard to schemata proceeding from the L1.

As observed by Guennette (2007), one of the reasons for the many conflicting results from previous studies on feedback may be that the feedback has not been done correctly—or, as the results from this study suggest, it may be not so much a matter of "correct" or "incorrect" feedback as it is the rationale behind the feedback. Evans, Hartshorn, and McCollum (2010) make a similar point by comparing scholars' failure to achieve consensus regarding feedback with the failures of early attempts at kidney transplants: "It wasn't that the kidney transplants 
were not going to work; it is that we were not doing it right" (p. 447). In this sense, the question about the value of feedback is not so much one of whether feedback can be valuable; it is a question of what kind of feedback is valuable (in a particular case) and how to ensure that the feedback provided is valuable. Further research that considers the underlying causes for errors, providing the basis for well rationalized feedback design offers opportunities to both better understand how learning works and help learners achieve better results. 


\section{References}

Amrhein, H. R., \& Nassaji, H. (2010). Written corrective feedback: What do students prefer and why? Canadian Journal of Applied Linguistics, 13, 95-127.

Apel, K. (2011). What is orthographic knowledge? Language, Speech, and Hearing Services in School, 42, 592-603.

Bailey, K. (1991). The use of diary studies in teacher education programs. In J. Richards \& D. Nunan (Eds.), Second language (pp. 215-226). Cambridge, UK: Cambridge University Press.

Bailey, M. (1998). Learning about language assessment. Boston, MA: Heinle Cengage Learning.

Barkaoui, K. (2007). Revision in second language writing: What teachers need to know. TESL Canada Journal, 25(1), 81-92.

Bates, L., Lane, J., \& Lange, E. (1993). Writing clearly: Responding to ESL compositions. Boston, MA: Heinle \& Heinle.

Beare, H., \& Slaughter, R. (1993). Education for twenty first century. London, UK: Routledge.

Bitchener, J. (2008). Evidence in support of written corrective feedback. Journal of Second Language Writing, 17, 102-118.

Bitchener, J., \& Ferris, D. R. (2012). Written corrective feedback in second language acquisition and writing. New York, NY: Routledge.

Bitchener, J., \& Knoch, U. (2008a). The value of focused approach to written corrective feedback. ELT Journal, 63(3), 204-211. 
Bitchener, J., \& Knoch, U. (2008b). The value of written corrective feedback for migrant and international students. Language Teaching Journal, 12(3), 409-431.

Bitchener, J., \& Knoch, U. (2009). The relative effectiveness of different types of direct written corrective feedback. System, 37, 322-329.

Bitchener, J., \& Knoch, U. (2010). The contributions of written corrective feedback to language development: A ten month investigation. Applied Linguistics, 31(2), 193-214.

Bitchener, J., Young, S., \& Cameron, D. (2005). The effect of different types of corrective feedback on ESL student writing. Journal of Second Language Writing, 14(3), 191-205.

Bolger, D. J., Minas, J., Burman, D. D., \& Brooth, J. (2008). Differential effects of orthography and phonological consistency in cortex for children with and without reading impairment. Neuropsychologia, 46(14), 3210-3224.

Brookhart, S., Moss, C., \& Long, B. (2008). Formative assessment that empowers. Educational Leadership, 66, 55-57.

Brown, H. D. (2001). Teaching by principles: An interactive approach to language pedagogy. (Second ed.). New York, NY: Longman.

Brown, J. D. (2005). Testing in language programs. A comprehensive guide to English language assessment. New York, NY: McGraw Hill.

Bruton, A. S. (2009). Improving accuracy is not the only reason for writing, and even if it were... System, 37(4), 600-613.

Burns, D. (2010). Doing action research in English language teaching. A guide for practitioners. New York, NY: Routledge. 
Chan, J. C. Y., \& Lam, S. (2010). Effects of different evaluative feedback on students' self efficacy in learning. Instructional Science, 38(1), 37-58.

Chandler, J. (2003). The efficacy of various kinds of error feedback for improvement in the accuracy and fluency of L2 student writing. Journal of Second Language Writing, 12, 267296.

Conrad, N. J. (2008). From reading to spelling and spelling to reading: Transfer goes both ways. Journal of Educational Psychology, 100, 869-878.

Council of Europe. (2001). Common European framework of reference for languages: Learning, reaching, assessment. Cambridge, UK: Cambridge University Press. Retrieved from https://www.coe.int/t/dg4/linguistic/source/framework_en.pdf

Coyle, D., Hood, P., \& Marsh, D. (2010). CLIL Content language integrated learning. Cambridge, UK: Cambridge University Press.

Cronnell, B. (1985). Language influences in the English writing of the third and sixth grade Mexican American students. Journal of Educational Research, 78(3), 168-173.

Crystal, D. (2003). English as a global language. Cambridge, UK: Cambridge University Press.

De Wet, K. (2010). The importance of ethical appraisal in social science research: Reviewing a faculty of humanities research committee. Journal of Academic Ethics, 8, 301-314.

Eales, F., Wilson, J., Clare, O., \& Oakes, S. (2011). Speakout: Pre-intermediate. London, UK: Pearson Education.

Ehri, L. (1986). Sources of difficulty in learning to spell and read. Advances in Developmental and Behavioral Pediatrics, 7, 121-195. 
Ellis, R. (1994). The study of second language acquisition. Oxford, UK: Oxford University Press.

Ellis, R. (2008). A typology of written corrective feedback types. ELT Journal, 28(2), 97-107.

Ellis, R., \& Barkhuizen, G. (2005). Analyzing learner language. Oxford, UK: Oxford University Press.

Ellis, R., Loewen, S., \& Erlam, R. (2006). Implicit and explicit corrective feedback and the acquisition of L2 grammar. Studies in Second Language Acquisition, 28(2), 339-368.

Evans, W. N., Hartshorn, K. J., McCollum, R. M., \& Wolfersbeger, M. (2010). Contextualizing corrective feedback in second language writing pedagogy. Language Teaching Research, $14(4), 445-463$.

Fashola, O., Drum, P., Mayer, R., \& Kang, S. (1996). A cognitive theory of orthographic transitioning: Predictable errors in how Spanish speaking children spell English words. American Educational Research Journal, 33(4), 825-843.

Fazio, L. L. (2001). The effects of corrections and commentaries on the journal writings of minority and majority language students. Journal of Second Language Writing, 10, 235249.

Ferris, D. (2004). The "grammar correction" debate in L2 writing: A response to Truscott (1996). Journal of Second Language Writing, 13, 49-62.

Ferris, D. R. (1999). The case for grammar correction in L2 classes. A response to Truscott. Journal of Second Language Writing, 8(1), 1-11.

Ferris, D. R. (2006). Does error feedback help student writers? New evidence on short and longterm effects of written correction. In K. Hyland \& F. Hyland (Eds.), Feedback in second 
language writing: Contexts and issues (pp. 81-104). Cambridge, UK: Cambridge University Press.

Ferris, D. R., \& Hedgcock, J. S. (1998). Teaching ESL composition: Purpose, process, and practice. Mahwah, NJ: Erlbaum.

Ferris, D. R., \& Roberts, B. (2001). Error feedback in L2 writing classes: How explicit does it need to be? Journal of Educational Psychology, 10(1), 161-184.

Foresman, S. (2007). Fresh reads for differentiated practice. London, UK: Pearson Education.

Gass, S. M., \& Varonis, E. M. (1994). Input, interaction, and second language production. Studies in Second Language Acquisition, 16, 282-200.

Georgiou, G. K., Parilla, R., \& Kirby, J. R. (2009). RAN components and reading developments from grade 3 to grade 5: What underlies their relationship? Scientific Studies of Reading, 13, $508-534$.

Ghandi, M., \& Maghsoudi, M. (2014). The effect of direct and indirect corrective feedback on Iranian EFL learners' spelling errors. English Language Teaching, 7(8), 53-62. http://dx.doi.org/10.5539/elt.v7n8p53

Goldstein, L. (2005). Teacher written commentary in second language classrooms. Ann Arbor, MI: University of Michigan Press.

Goldstein, L. (2006). Feedback and revision in second language writing: Contextual, teacher and student variables. In K. Hyland \& F. Hyland (Eds.), Feedback in second language writing: Contexts and issues. (pp. 185-205). New York, NY: Cambridge University Press.

Gould, R., \& Colleen, R. (2013). Introductory statistics. Boston, MA: Pearson Education. 
Gregory, M., \& Carroll, S. (1978). Language and situation: Language varieties and their social contexts. London, UK: Routledge and Kegan Paul.

Grossi, G., Murphy, J., \& Boogan, J. (2009). Word and pseudoword superiority effects in ItalianEnglish bilinguals. Bilingualism: Language and Cognition, 12, 113-120.

Gudmundsdottir, G. B., \& Utne, B. V. (2010). An exploration of piloting and access as action research. Educational Action Research, 18, 359-372.

Guennette, D. (2007). Is feedback pedagogically correct? Journal of Second Language Writing, $16,40-63$.

Hattie, J., \& Timperley, H. (2007). The power of feedback. Journal of Second Language Writing, $77,81-112$.

Hein, G. E. (1991). Constructivist Learning Theory. Paper presented at the Committee of Education and Cultural Action (CECA) Conference, Jerusalem, Israel. Retrieved from https://www.exploratorium.edu/education/ifi/constructivist-learning

Hendrickson, J. (1977). Error in foreign language teaching: Recent theory, research and practice. Modern Language Journal, 62, 387-398.

Hendrickson, J. (1980). The treatment of written work. Modern Language Journal, 64, 216-221.

Hilte, M., \& Reitsma, P. (2008). What type of computer assisted exercise supports young less skilled spellers in resolving problems in open and closed syllable words? Annals of Dyslexia, 58, 97-114.

Hopkins, D. (1985). A teacher's guide to classroom research. Philadelphia, PA: Open University Press. 
Housen, A., \& Kuiken, F. (2009). Complexity, accuracy, and fluency in second language acquisition. Applied Linguistics, 30(4), 461-473.

Hyland, F. (2003). Focusing on form: Student engagement with teacher feedback. System, 31, $217-230$.

Hyland, K., \& Hyland, F. (2006). Feedback on second language students' writing. Language Teaching, 39, 77-95.

Jacobson, N., Gerwurtz, R., \& Haydon, E. (2007). Ethical review of interpretative research: Problems and solutions. IRB: Ethics \& Human Research, 29(5), 1-8.

Joy, R. (2017). The concurrent development of spelling skills in two languages. Internal Electronic Journal of Elementary Education., 3(2), 105-121.

Kelley, K., Clark, B., Brown, V., \& Sitzia, T. (2003). Good practice in the conduct and reporting of survey research. In International Journal of Quality Health Care (Vol. 15, pp. 261-266).

Kelter, D., \& Ekman, P. (2000). Facial expression of emotion. In M. Lewis \& J. Haviland-Jones (Eds.), Handbook of emotions (2nd ed., pp. 236-245). New York, NY: Guilford.

Keltner, D., Ekman, P., Gonzaga, G. C., \& Beer, J. (2003). Facial expression of emotion. In R. J. Davidson, K. R. Scherer, \& H. H. Goldsmith (Eds.), Handbook of Affective Sciences (pp. 415-432). New York: Oxford University.

Kember, D. (2000). Action learning and action research: Improving the quality of teaching and learning. London, UK: Kogan Page.

Kemp, N. (2006). Children's spelling of base inflected and derived words: Links with morphological awareness. An Interdisciplinary Journal, 19(7), 737-765. 
Kidd, R. (1992). Teaching ESL grammar through dictation. TESL Canada Journal, 10(1), 49-61.

Kim, S., Ubel, P., \& De Vries, R. (2009). Pruning the regulatory tree. Nature, 457, 534-535.

Kirby, J. R., Desrochers, A., Roth, L., \& Lai, S. S. V. (2008). Longitudinal predictors of word reading development. Canadian Psychology/Psychologie Cannadien, 49(2), 103-110.

Krashen, S. D. (1984). Writing, research, theory, and application. Oxford, UK: Pergham Press.

Kvale, S. (1989). Issues in validity in quantitative research. Lund, Sweden: Studenlitteratur.

Lalande, J. F. (1982). Reducing composition errors, an experiment. Modern Language Journal, $66,140-149$.

Lee, J. (2008). Understanding teacher's written feedback practices in Hong Kong secondary classrooms. Journal of Secondary Writing, 17, 69-85.

Littlejohn, S. W., \& Foss, K, A. (2011). Theories of human communication. Long Grove, IL: Waveland Press.

Long, M. (2005). Second language needs analysis. Cambridge, UK: Cambridge University Press.

Lukatela, G., Popadic, D., Ognjenovic, P., \& Tirvety, M. T. (1980). Lexical decision in a phonologically shallow orthography. Memory and Cognition, 8(2), 124-132.

Maleki, A., \& Eslami, E. (2013). The effects of written corrective feedback techniques on EFL students' control over grammatical construction of their written English. Theory and Practice in Language Studies, 3(7), 1250-1257.

Merriam, S. B. (1998). Qualitative research and case study applications in education. San Francisco, CA.: Jossey-Bass. 
Miles, M. B., \& Huberman, A. M. (1994). Qualitative data analysis (2nd ed.). Thousand Oaks, CA: Sage.

Mohammad, A., \& Benis, A. R. S. (2014). The effect on transcribing on beginning learners' dictation. Theory into Practice, 4(11), 2203-2208.

Moss, L. (2003). Jerome Bruner: Language, culture, self. Canadian Psychology, 44(1), 77-83.

Murphy, E., \& Dingwall, R. (2007). Informed consent, anticipatory regulation and ethnographic practice. Social Science \& Medicine, 65(11), 2223-2234.

Nunan, D., \& Bailey, K. (2009). Exploring second language classroom research. Boston, MA: Heinle Cengage Learning.

OECD 2016. (2016). PISA 2015 results (volume I): Excellence and equity in education, PISA. Retrieved from http://www.oecd.org/education/pisa-2015-results-volume-i9789264266490-en.htm

Oller, J. W. (1978). Pragmatics and language testing. In B. Polsky (Ed.), . Arlington, VA: Center for Applied Linguistics.

Ouellet, G., \& Senechal, M. (2008). Pathways to literacy: A study on invented spelling and its role in learning to read. Child Development, 19(4), 899-913.

Owren, M. J., \& Barochorowski, J. A. (2003). Reconsidering the evolution of nonlinguistic communication: The case of laughter. Journal of Nonverbal Behavior, 27(3), 183-200.

Pagan, B. (2006). Positive contributions of constructivism to educational design. Europe's Journal of Psychology, 2(1).

Raynolds, L. B., \& Uhry, J. K. (2010). The invented spelling of non-Spanish phonemes by 
Spanish-English bilinguals and English monolingual kindergarteners. Reading and Writing, 23(5), 495-513.

Reppen, R. (2010). Using corpora in the language classroom. New York, NY: Cambridge University Press.

Richards, J. C. (2001). Curriculum development in language teaching. Cambridge, UK: Cambridge University Press.

Richards, J. C., \& Schmidt, R. (2002). Longman dictionary of language teaching and applied linguistics. (3rd ed.). London, UK: Pearson Education.

Richardson, V. (2003). Constructivist pedagogy. Teacher College Records, 105, 1623-1640.

Rob, T., Ross, S., \& Shortreed, I. (1986). Salience of feedback on error and its effect on EFL writing quality. TESOL Quarterly, 20(1), 83-95.

Russel, J., \& Spada, N. (2006). The effectiveness of corrective feedback for the acquisition of L2 grammar: A meta-analysis of the research. In J. Norris \& L. Ortega (Eds.), Synthesizing research on language learning and teaching (pp. 133-164). Amsterdam, Netherlands: John Benjamins.

Sadler, D. R. (1989). Formative assessment and the design of instructional systems. Instructional Science, 18(2), 119-144.

Saito, H. (1994). Teacher's practices and student's preferences for feedback on second language writing: A case study of adult ESL learners. TESL Canada Journal, 11(2).

Sanders, M., \& Banda, G. (1997). Questioning the validity of research instruments: An essential step in educational research. Journal of the Southern African Association for Research in Mathematics, Science and Technology Education, 1(1), 12-25. 
Santos, M., Lopez-Serrano, S., \& Manchon, R. M. (2010). The differential effect of two types of direct written corrective feedback on noticing and uptake: Reformulation vs. error correction. IJES, 10(1), 131-154.

Schaertel, S. A. (2012). Giving feedback: An integral part of education. Best Practice and Research: Clinical Anaesthesiology, 26(1), 77-87.

Schmidt, R. (2001). Cognition and second language instruction. New York, NY: Cambridge University Press.

Schmidt, R. (2010). Attention, awareness, and individual differences in language learning. Proceedings of ClaSIC, 4, 731-737.

Schuh, K. L. (2003). Knowledge construction in the learner centered classroom. Journal of Educational Psychology, 2, 426-442.

Semke, H. (1984). The effects of red pen. Foreign Language Annals, 17, 195-202.

Sergey, L. (2008). Top languages in global information production. The Canadian Journal of Library and Information Practice and Research, 3(2).

Sheen, Y. (2007). The effect of focused written feedback and language aptitude on ESL learners' acquisition of articles. TESOL Quarterly, 41, 255-284.

Slaven, R., \& Cheung, A. (2004). How do English language learners learn to read? Educational Leadership, 61, 52-57.

Storch, N. (2010). Critical feedback on written corrective feedback research. International Journal of English Studies, 10(2), 29-46.

Tarone, E., \& Yule, G. (1989). Focus on the language learner: Approaches to 130 identifying 
and meeting the needs of second language learners. Oxford, UK: Oxford University Press.

Templeton, S., \& Morris, D. (2000). Spelling. In M. Kamil, P. Mosenthal, P. Pearson, \& R. Barr (Eds.), Handbook of reading research (pp. 525-543). Mahwah, NJ: Erlbaum.

Tong, X., Mc Bride-Chang, C., Shu, H., \& Wong, A. .-Y. (2009). What exactly is yait anyway. The role of semantics in orthographic learning. Journal of Experimental Child Psychology, 104, 239-251.

Torto, R. T. (2014). Language in communication in a multilingual setting: A case study of a cross section of first year students of the University of Cape Coast, Ghana. Language in India, 14(12), 339-359.

Trim, J. (1978). Some possible lines of development of an overall structure for a European unit credit scheme for foreign language learning by adults. Strasbourg, France: Council of Europe.

Truscott, J. (1996). The case against grammar correction in L2 writing classes. Language Learning, 46, 327-369.

Truscott, J. (1997). A problem and a non-problem for English learners. English Teaching and Learning, 22(5), 59-57.

Truscott, J. (1999). The case against grammar correction in L2 classes: A response to Ferris. Journal of Second Language Writing, 8, 111-122.

Truscott, J. (2004). Evidence and conjecture on the effects of correction: A response to Chandler. Journal of Second Language Writing, 4, 337-343.

Truscott, J. (2007). The effect of error correction on learners' ability to write accurately. Journal of Second Language Writing, 16(4), 255-272. 
Truscott, J. (2010). Further thoughts on Anthony Bruton's critique of the correction debate. Journal of Second Language Writing, 16, 255-272.

Van Beuninge, C. (2010). Corrective feedback in L2 writing: Theoretical perspectives, empirical insights, and future directions. International Journal of English Studies, 10(2), 1-27.

Van Beuninge, C. G., Dejong, N. H., \& Kuiken, F. (2012). Evidence on the effectiveness of comprehensive error correction in second language writing. Language Learning, 62(1), 141.

Verhoeven, L., Schreuder, R., \& Baayen, H. R. (2006). Learnability of graphostatic rules in visual word identification. Learning and Instruction, 16, 538-548.

Wallerstein, I., Juma, C., Keller, E. F., Kocka, J., Lecourt, D., Mudimbe, V. Y., ... Trouillot, M. R. (1998). Luk samfundsvidenskaberne op! Report from “The Gulbenkian Commission of the Restructuring of the Social Sciences." Copenhagen, Denmark: Roskilde Universitetsforlag.

Wiggins, G. (1997, June). Feedback: How learning occurs. Paper presented at the American Association of Higher Education Conference on Assessment Quality, Miami Beach, FL.

Wiggins, G., \& McTighe, J. (2006). Understanding by design. A framework for effecting curriculum assessment. Alexandria, VA: ASCD (Association for Supervision and Curriculum Development). 


\section{Appendix A: Research Consent Form}

Department of Culture and Foreign Languages

Universidad de la Sabana

Attn: Ms. Nohora Bryan

The teacher researcher Stella Lequerica from Universidad de la Sabana invites her level 4 pre-intermediate students to participate in her research study. I hope to learn about the best way to provide Written Corrective Feedback (WCF) to them. The students of this population have been selected because they are my students and I wish to find out about the best way to help them.

During the procedure the students will go through a dictation process whereby students will transcribe the exact words of a passage that the teacher will read to them aloud. This is with the purpose of creating an artifact to serve as the data collection mechanism for the research. Each dictation process will take place during three instances at their respective classrooms in Universidad de la Sabana.

For the above-mentioned reason I request your consent. Your signature below indicates that you have read and understood the information provided above, and that you agree to allow her level 4 pre-intermediate students to participate in her research study.

Stella Lequerica

Teacher Researcher

Nohora Bryan

Director Department of Foreign Languages and Culture 


\section{Appendix B: Consent Letter Parents}

Dear parent/guardian of [name of child]:

Your child is invited to participate in a research study conducted by Stella Lequerica, homeroom teacher of $4^{\text {th }}$ grade. As a teacher-researcher in this study, I hope to learn about the best way to provide Written Corrective Feedback (WCF) on spelling to the students. The students of this population have been selected because I wish to find out about the best way to help them.

During the procedure the students would go through a dictation process in which they would transcribe the exact words of a passage that the teacher would read to them aloud. This would have the purpose of creating an artifact to serve as the main data collection instrument for the study. There would be three instances of such dictations during their respective classes.

If you have any questions about the study, please feel free to contact me by telephone or e-mail. ${ }^{1}$ Your signature indicates that you have read and understood the information provided above, and that you willingly agree to allow your child to participate.

Signature of parent or guardian

Date

${ }^{1}$ The teacher-researchers' telephone number and e-mail address, provided in the actual letter to parents/guardians, have been omitted from the version of the consent letter provided in this appendix. 


\section{Appendix C: Dictation Texts Uni Sabana Population}

\section{C.1 150 words: Juan Oliveira}

Juan Oliveira was born in Argentina, grew up in Paraguay and now lives in Brazil. He says he loves the three countries equally and he works in all three of them every day.

Juan is a tour guide in Foz Do Iguazu, a Brazilian town which is close to the border of both Argentina and Paraguay. He takes tourists around the Iguazu falls, of the great natural wonders of the world.

First, he shows tourists the waterfall from the Brazilian side. Then, they cross the border to see the water, from the Argentinian side. After that, they go on a boat trip which takes them under the waterfall. Finally, he takes them on the short journey to Ciudad del Este in Paraguay to do tax free shopping.

He says the falls are amazing, especially in the rainy season. He sees them every day, and he never gets tired of them.

\section{C.2 163 words: The Motorcycle Diaries}

Before he became a famous revolutionary, Ché Guevara was simply Ernesto Guevara de la Serna from Argentina, a student looking for fun. He was studying when he decided to travel across Latin America by motorbike with his friend Alberto.

They slept on floors, met girls, and drank beer. They walked through deserts and up mountains and spent some time working in a leper colony in Peru. Their only problem was with transport, once crashing a motorbike into a cow but it was an amazing journey. They travelled 500 miles in 4 months.

While he was travelling, Ernesto met many poor people from Chile, Peru, and Bolivia and this opened his eyes to the lives of poor people. At the end of the journey he stopped 
studying to be a doctor, and began his life's work, fighting for the poor. Later Guevara and his friend Alberto wrote books about this journey, and in 2004 the story was made into a film, The Motorcycle Diaries.

\section{C.3 145 words: Easter Island}

We would like to go to Easter Island to live with the local people for three months. Easter Island is one of the great mysteries of the world. It has many famous stone statues of heads, but no one knows who made them or why.

Our plan is to talk to the islanders about their history and about their present and future. We will ask them about their lives and what they think of the statues. We want to learn how the world's most isolated people live, what they eat, and what they do for entertainment, and what they think of the modern world of computers and other technology.

We will record all the interviews on film. We will also keep a diary of our own experiences and eventually, we hope to make a TV documentary and write a book about our time on the island. 


\section{Appendix D: Dictation Texts}

\section{D.1 119 words: Wish Comes True}

Dear Diary,

When I went to bed last night, I made a wish. When I woke up this morning, I saw that my wish had come true. A blanket of snow covered the ground.

Mom fixed me pancakes before I put on my warmest coat, gloves, and boots. I met Lisa at Cobb Hill with my sled.

Sledding down Cobb Hill is more fun than any ride at the amusement park. I love coasting down with the wind in my face and the sun on my back. It's a long trek back up; it's worth it!

After we'd been sledding a while, we met up with Nan and Betty. They had a toboggan, and we all went down together.

\section{D.2 105 w Why I Love Thanksgiving}

Thanksgiving is the very best day of all season. This national holiday falls on the fourth Thursday in November. It is a day to remember the first Americans. Banks, post offices, and most stores close for Thanksgiving Day. Schools close for the long weekend.

Thanksgiving became a holiday in 1863. Each year since then, American families gave gathered for a big meal. The centerpiece of most Thanksgiving dinners is the turkey. This allAmerican bird tastes great with stuffing and cranberry sauce. Sweet potatoes and other vegetables add to the feast. And don't forget pumpkin pie for dessert. Nobody leaves the table hungry on Thanksgiving. 


\section{D.2.1 146 words}

Sometimes a certain species of animal dies off naturally or through another cause, such as hunting by humans. In these cases, there will be an increase in the number of the animals that the dying species feeds on.

An example of this process can be seen in the relationship among wolves and panthers and deer. Wolves and panthers have largely disappeared from the United States. Consequently, their natural prey, deer have multiplied. There are more deer in the country than there were before colonists settled the land centuries ago. Because the deer population has been very large, herds of deer quickly eat up all the food in some areas. Of course, when food is lacking, the animals starve. Human beings can help an area recover its natural balance. In some cases, people introduce natural enemies into an area to control the numbers of the prey animal. 


\section{Appendix E: Lesson Planning}

\section{Lesson Plan}

Broad Goal: To prompt a communicative situation in the target language through general awareness-raising of spelling error/mistakes.

Specific Goals: The student will be able to use target language to:

- Participate in social interaction through the exchange of information, ideas, opinions, attitudes, feelings, experience.

- To improve written spelling accuracy.

Assumed knowledge: I am assuming that most of the vocabulary is relatively familiar for the students.

Anticipated problems: I have planned this lesson four three sessions of 45 minutes each, however the timing is not always right. This could be overly ambitious as the timings are somewhat arbitrary.

Material: Paper, pencil, textbook (from where the dictations came from).

\begin{tabular}{|l|l|l|l|}
\hline Steps & Task & Strategy & Purpose \\
\hline Step 1 & $\begin{array}{l}\text { Researcher highlights some of the } \\
\text { benefits of dictations such as: } \\
\text { Makes the students and teacher } \\
\text { aware of their errors; that they } \\
\text { could occur due to reasons } \\
\text { such phonological, } \\
\text { grammatical, or both hence, } \\
\text { highlighting the benefits of } \\
\text { focusing on one error category } \\
\text { which in this study is spelling. }\end{array}$ & Cistening and \\
& & & about the benefits of \\
& & & \\
\hline
\end{tabular}




\begin{tabular}{|c|c|c|c|}
\hline & $\begin{array}{l}\text { Shows students the kinds of } \\
\text { spelling error they are prone to } \\
\text { make. } \\
\text { Gives students practice in } \\
\text { comprehending and } \\
\text { transcribing English texts. } \\
\text { Gives practice in correct forms } \\
\text { of speech. } \\
\text { Help develop all four language } \\
\text { skills listening, reading, } \\
\text { writing, and speaking in an } \\
\text { integrative way }\end{array}$ & & \\
\hline $\begin{array}{l}\text { Step 2: } \\
\text { Warm-up }\end{array}$ & $\begin{array}{l}\text { Generated class discussion: } \\
\text { Researcher asks students about the } \\
\text { meaning of some words. This } \\
\text { prompts students' interventions as } \\
\text { they try to give their definitions. } \\
\text { Teacher researcher will encourage } \\
\text { them to figure it out from context. If } \\
\text { they are not able to come up with the } \\
\text { correct meaning, the researcher will } \\
\text { give it to them. In this way the } \\
\text { researcher pre-teaches some of the } \\
\text { vocabulary and contextualizes it. }\end{array}$ & Conversational & $\begin{array}{l}\text { Familiarize students } \\
\text { with some of the } \\
\text { vocabulary they are } \\
\text { going to hear and that } \\
\text { they will be required } \\
\text { to transcribe. }\end{array}$ \\
\hline $\begin{array}{l}\text { Step 3: } \\
\text { Awareness }\end{array}$ & $\begin{array}{l}\text { The researcher reads the dictation } \\
\text { text through once, at a normal speed. } \\
\text { The students should only listen. }\end{array}$ & Getting the gist & $\begin{array}{l}\text { Cognitive strategy. It } \\
\text { will contribute to } \\
\text { make the content of } \\
\text { the dictation more } \\
\text { meaningful. This step } \\
\text { serves to create }\end{array}$ \\
\hline
\end{tabular}




\begin{tabular}{|c|c|c|c|}
\hline & & & $\begin{array}{l}\text { awareness about } \\
\text { context. }\end{array}$ \\
\hline $\begin{array}{l}\text { Step 4: } \\
\text { Transcription }\end{array}$ & $\begin{array}{l}\text { The teacher reads the dictation again } \\
\text { but stops at every meaningful unit. } \\
\text { Students write what they hear. For } \\
\text { any word they cannot transcribe they } \\
\text { should leave a blank. Finally, the } \\
\text { teacher clarifies any vocabulary that } \\
\text { seemed difficult. }\end{array}$ & Contextualizing & $\begin{array}{l}\text { Contribute to } \\
\text { meaning in order to } \\
\text { enhance } \\
\text { comprehension and } \\
\text { thus, eliminate or } \\
\text { reduce the extraneous } \\
\text { variable associated } \\
\text { with unknown words. }\end{array}$ \\
\hline $\begin{array}{l}\text { Step 5: } \\
\text { Revision }\end{array}$ & $\begin{array}{l}\text { The researcher reads the dictation a } \\
\text { third time at a normal speaking } \\
\text { speed. The students should check } \\
\text { their work and make any last } \\
\text { changes. }\end{array}$ & $\begin{array}{l}\text { Proof reading } \\
\text { revision. }\end{array}$ & $\begin{array}{l}\text { To enhance spelling } \\
\text { ability. }\end{array}$ \\
\hline
\end{tabular}




\section{Appendix F: Detailed Statistical Results from Different Populations/Groups}

The tables in this appendix show how the statistics of P1G1, P1G2, P1G3, P2G1, P2G2, and P2G3 after the application of the direct and indirect WCF treatment were obtained. The

mean, variance $\left(\sigma^{2}\right)$ and standard deviation $(\sigma)$, were found. These were used to run the one-way ANOVA statistical test. The tables provide information about each group within each population such as: The number of words of the artifact, the type of WCF provided, the number of errors per subject (represented under the column $X$ ), the average number of errors per group (represented as $X$ average). The $D$ in the tables represents the distance of each subject's errors from the means. The $D$ is calculated by subtracting the number of errors from the means. For example: In table 1 P1G1, subject 1 had 38 errors (38 under X). Then 38 is subtracted from the average errors of this group which is 19 and the result is $19(38-19=19) . D 2$ is $D$ squared to avoid negative numbers. With this information the variance and standard deviation of each group is calculated. The variance is the average of the squared differences from the mean (a measure of dispersion) and the standard deviation is the square root of the variance. Final in P1G1, P1G2 and P2G1, P2G2, is the last dictation the researcher did after having applied the treatment in the two previous occasions. These results were not returned to students.

Tables 4, 5, and 6 shows the statistics of P1G1. 
Table 1

Population 1, Group 1, 150 words, indirect feedback.

\begin{tabular}{|c|c|c|c|c|}
\hline Subject & $\underline{X}$ & $\underline{X}$ average & $\underline{\mathrm{D}}$ & $\underline{\mathrm{D} 2}$ \\
\hline 1 & $\overline{38}$ & 19 & $\overline{19}$ & $\overline{361}$ \\
\hline 2 & 3 & 19 & -16 & 256 \\
\hline 3 & 7 & 19 & -12 & 144 \\
\hline 4 & 20 & 19 & 1 & 1 \\
\hline 5 & 3 & 19 & -16 & 256 \\
\hline 6 & 39 & 19 & 20 & 400 \\
\hline 7 & 20 & 19 & 1 & 1 \\
\hline 8 & 20 & 19 & 1 & 1 \\
\hline 9 & 20 & 19 & 1 & 1 \\
\hline 10 & 20 & 19 & 1 & \\
\hline
\end{tabular}

$\sigma 12.56$

$\sigma^{2} 158$

Mean 19

Table 2.

Group 1, 163 words, direct feedback.

\begin{tabular}{|c|c|c|c|c|}
\hline Subject & $\underline{X}$ & $\underline{X \text { average }}$ & $\underline{\mathrm{D}}$ & D2 \\
\hline 1 & $\overline{59}$ & 20.4 & $3 \overline{8.6}$ & $14 \overline{89.96}$ \\
\hline 2 & 9 & 20.4 & -11.4 & 129.96 \\
\hline 3 & 9 & 20.4 & -11.4 & 129.96 \\
\hline 4 & 16 & 20.4 & -4.4 & 19.36 \\
\hline 5 & 2 & 20.4 & -18.4 & 338.56 \\
\hline 6 & 54 & 20.4 & 33.6 & 1128.96 \\
\hline 7 & 17 & 20.4 & -3.4 & 11.56 \\
\hline 8 & 13 & 20.4 & -7.4 & 54.76 \\
\hline 9 & 25 & 20.4 & 4.6 & 21.16 \\
\hline 10 & 0 & 20.4 & -20.4 & 416.16 \\
\hline \multicolumn{5}{|l|}{$\sigma 20.4$} \\
\hline \multicolumn{5}{|l|}{$\sigma^{2} 415.6$} \\
\hline \multicolumn{5}{|l|}{ Mean 20.4} \\
\hline
\end{tabular}


Table 3.

Population 1, Group 3, 145 words, final score.

\begin{tabular}{|c|c|c|c|c|}
\hline Subject & $\underline{X}$ & $\underline{X}$ average & $\underline{\mathrm{D}}$ & $\underline{\mathrm{D} 2}$ \\
\hline 1 & 39 & 15.1 & 23.9 & 571.21 \\
\hline 2 & 4 & 15.1 & -11.1 & 123.21 \\
\hline 3 & 7 & 15.1 & -8.1 & 65.61 \\
\hline 4 & 16 & 15.1 & 0.9 & 0.81 \\
\hline 5 & 7 & 15.1 & -8.1 & 65.61 \\
\hline 6 & 35 & 15.1 & 19.9 & 396.01 \\
\hline 7 & 16 & 15.1 & 0.9 & 0.81 \\
\hline 8 & 12 & 15.1 & -3.1 & 9.61 \\
\hline 9 & 7 & 15.1 & -8.1 & 65.61 \\
\hline 10 & 8 & 15.1 & -7.1 & 50.41 \\
\hline 12.24 & & & & \\
\hline
\end{tabular}

Tables 7, 8, and 9 show the statistics of Population 1, Group 2.

Table 4.

Population 1, Group 2, 150 words, direct feedback.

\begin{tabular}{|c|c|c|c|c|}
\hline Subject & $\underline{X}$ & $X$ average & $\mathrm{D}$ & D2 \\
\hline 1 & 8 & 15.7 & -7.7 & 52.9 \\
\hline 2 & 29 & 15.7 & 13.3 & 176.89 \\
\hline 3 & 7 & 15.7 & -8.7 & 75.69 \\
\hline 4 & 5 & 15.7 & 10.7 & 114.49 \\
\hline 5 & 35 & 15.7 & 19.3 & 372.49 \\
\hline 6 & 28 & 15.7 & 12.3 & 151.29 \\
\hline 7 & 17 & 15.7 & 1.3 & 1.69 \\
\hline 8 & 5 & 15.7 & -10.7 & 114.49 \\
\hline 9 & 19 & 15.7 & 3.3 & 10.89 \\
\hline 10 & 4 & 15.7 & -11.7 & 136.89 \\
\hline $\begin{array}{l}134.9 \\
15.9\end{array}$ & & & & \\
\hline
\end{tabular}


Table 5.

Population 1, Group 2, 163 words, indirect feedback.

\begin{tabular}{|c|c|c|c|c|}
\hline Subject & $\underline{X}$ & $\underline{X}$ average & $\underline{\mathrm{D}}$ & $\underline{\mathrm{D} 2}$ \\
\hline 1 & $\overline{16}$ & 25.3 & -9.3 & 86.49 \\
\hline 2 & 34 & 25.3 & 8.7 & 75.69 \\
\hline 3 & 24 & 25.3 & -1.3 & 1.69 \\
\hline 4 & 12 & 25.3 & -13.3 & 176.89 \\
\hline 5 & 24 & 25.3 & -1.3 & 1.69 \\
\hline 6 & 55 & 25.3 & 29.7 & 882.09 \\
\hline 7 & 17 & 25.3 & -8.3 & 68.89 \\
\hline 8 & 13 & 25.3 & -12.3 & 151.29 \\
\hline 9 & 45 & 25.3 & 19.7 & 388.09 \\
\hline 10 & 13 & 25.3 & -12.3 & 151.29 \\
\hline
\end{tabular}

$\sigma 14.7$

$\sigma^{2} 216.4$

Mean 25.3

Table 6.

Population 1, Group 2, 145 words, final.

\begin{tabular}{|c|c|c|c|c|}
\hline Subject & $\underline{X}$ & $X$ average & D & D2 \\
\hline 1 & 13 & 14 & $\overline{-1}$ & $\overline{1}$ \\
\hline 2 & 25 & 14 & 11 & 121 \\
\hline 3 & 8 & 14 & -6 & 36 \\
\hline 4 & 6 & 14 & -8 & 64 \\
\hline 5 & 13 & 14 & -1 & 1 \\
\hline 6 & 32 & 14 & 18 & 324 \\
\hline 7 & 13 & 14 & -1 & 1 \\
\hline 8 & 3 & 14 & -11 & 121 \\
\hline 9 & 24 & 14 & 10 & 100 \\
\hline 10 & 3 & 14 & -11 & 121 \\
\hline \multicolumn{5}{|l|}{$\sigma 9.94$} \\
\hline \multicolumn{5}{|l|}{$\sigma^{2} 98.9$} \\
\hline \multicolumn{5}{|l|}{ Mean 14} \\
\hline
\end{tabular}


Table 10 shows the statistics for Population 1, Group 3.

Table 7.

Population 1, Group 3, 145 words, no feedback.

\begin{tabular}{|c|c|c|c|c|}
\hline Subject & $\underline{X}$ & $X$ average & D & D2 \\
\hline 1 & $\overline{22}$ & 13 & $\overline{9}$ & 81 \\
\hline 2 & 31 & 13 & 18 & 324 \\
\hline 3 & 11 & 13 & -2 & 4 \\
\hline 4 & 10 & 13 & -3 & 9 \\
\hline 5 & 9 & 13 & -4 & 16 \\
\hline 6 & 12 & 13 & -1 & 1 \\
\hline 7 & 6 & 13 & -7 & 49 \\
\hline 8 & 10 & 13 & -3 & 9 \\
\hline 9 & 7 & 13 & -6 & 36 \\
\hline 10 & 12 & 13 & -1 & 1 \\
\hline \multicolumn{5}{|l|}{$\sigma 58.9$} \\
\hline \multicolumn{5}{|l|}{$\sigma^{2} 7.7$} \\
\hline Mean 13 & & & & \\
\hline
\end{tabular}

Tables 11, 12, and 13 show the statistics for P2G1, P2G2, and P2G3. P2G1 and P2G2 received the same WCF in both occasions the treatment was applied; P2G1 only received indirect feedback and P2G2 only received direct feedback.

Table 8.

Population 2, Group 1, 119 words, indirect.

\begin{tabular}{|c|c|c|c|c|}
\hline Subject & $\underline{X}$ & $\underline{X \text { average }}$ & $\underline{D}$ & D2 \\
\hline 1 & 7 & 12.25 & -5.25 & 27.56 \\
\hline 2 & 11 & 12.25 & -1.25 & 1.56 \\
\hline 3 & 17 & 12.25 & 4.75 & 22.56 \\
\hline 4 & 4 & 12.25 & -8.25 & 68.06 \\
\hline 5 & 9 & 12.25 & -3.25 & 10.56 \\
\hline 6 & 21 & 12.25 & 8.75 & 76.56 \\
\hline 7 & 12 & 12.25 & -0.25 & 0.06 \\
\hline 8 & 17 & 12.5 & 4.75 & 22.56 \\
\hline \multicolumn{5}{|l|}{$\sigma 5.7$} \\
\hline \multicolumn{5}{|l|}{$\sigma^{2} 32.79$} \\
\hline \multicolumn{5}{|l|}{ Mean 12.25} \\
\hline
\end{tabular}


Table 9.

Population 2, Group 1, 105 words, indirect.

\begin{tabular}{|c|c|c|c|c|}
\hline Subject & $\underline{X}$ & $\underline{X}$ average & D & D2 \\
\hline 1 & 15 & 16.13 & -1.13 & 1.28 \\
\hline 2 & 18 & 16.13 & 1.87 & 3.50 \\
\hline 3 & 23 & 16.13 & 6.87 & 47.20 \\
\hline 4 & 15 & 16.13 & -1.13 & 1.28 \\
\hline 5 & 7 & 16.13 & -9.13 & 83.36 \\
\hline 6 & 9 & 16.13 & -7.13 & 50.84 \\
\hline 7 & 28 & 16.13 & 11.87 & 140.90 \\
\hline 8 & 14 & 16.13 & -2.13 & 4.54 \\
\hline $\begin{array}{ll}\sigma & 6.9 \\
\sigma^{2} & 47.55 \\
M & 16\end{array}$ & & & & \\
\hline
\end{tabular}

Table 10.

Population 2, Group 1, 115 words, final.

\begin{tabular}{|c|c|c|c|c|}
\hline Subject & $\underline{X}$ & $X$ average & D & D2 \\
\hline 1 & 10 & 11.5 & $-\overline{1.5}$ & 2.25 \\
\hline 2 & 11 & 11.5 & -0.5 & 0.25 \\
\hline 3 & 15 & 11.5 & 3.5 & 12.25 \\
\hline 4 & 9 & 11.5 & -2.5 & 6.25 \\
\hline 5 & 9 & 11.5 & -2.5 & 6.25 \\
\hline 6 & 10 & 11.5 & -1.5 & 2.25 \\
\hline 7 & 16 & 11.5 & 4.5 & 20.25 \\
\hline 8 & 12 & 11.5 & 0.5 & 0.25 \\
\hline \multicolumn{5}{|l|}{$\sigma 1.6$} \\
\hline \multirow{2}{*}{\multicolumn{5}{|c|}{$\sigma^{2} 7.1$}} \\
\hline & & & & \\
\hline
\end{tabular}

Tables 14, 15, and 16 show the statistics of Population 2, Group 2. Here, P2G1 received only direct feedback and P2G2 received direct only feedback. 
Table 11.

Population 1, Group 2, 119 words, direct.

\begin{tabular}{|c|c|c|c|c|}
\hline Subject & $\underline{X}$ & $X$ average & $\underline{D}$ & D2 \\
\hline 1 & 29 & 16.8 & 12.2 & 148.84 \\
\hline 2 & 17 & 16.8 & 0.2 & 0.04 \\
\hline 3 & 16 & 16.8 & -0.8 & 0.64 \\
\hline 4 & 21 & 16.8 & 4.2 & 17.64 \\
\hline 5 & 10 & 16.8 & -6.8 & 46.24 \\
\hline 6 & 6 & 16.8 & -10.8 & 116.64 \\
\hline 7 & 30 & 16.8 & 13.2 & 174.24 \\
\hline 8 & 16 & 16.8 & -0.8 & 0.64 \\
\hline 9 & 8 & 16.8 & -8.8 & 77.44 \\
\hline 10 & 15 & 16.8 & -1.8 & 3.24 \\
\hline \multicolumn{5}{|l|}{$\sigma 8.1$} \\
\hline \multicolumn{5}{|l|}{$\sigma^{2} 98.9$} \\
\hline \multicolumn{5}{|l|}{ Mean 14} \\
\hline
\end{tabular}

Table 12.

Population 2, Group 2, 108 words, direct.

\begin{tabular}{|c|c|c|c|c|}
\hline Subject & $\underline{X}$ & $\underline{X \text { average }}$ & $\underline{\mathrm{D}}$ & $\underline{\mathrm{D} 2}$ \\
\hline 1 & $\overline{14}$ & 15.2 & $-\overline{1.2}$ & $\overline{1.44}$ \\
\hline 2 & 16 & 15.2 & 0.8 & 0.64 \\
\hline 3 & 18 & 15.2 & 2.8 & 7.84 \\
\hline 4 & 17 & 15.2 & 1.8 & 3.24 \\
\hline 5 & 7 & 15.2 & -8.2 & 67.24 \\
\hline 6 & 13 & 15.2 & -2.2 & 4.84 \\
\hline 7 & 29 & 15.2 & 13.8 & 190.44 \\
\hline 8 & 13 & 15.2 & -2.2 & 4.84 \\
\hline 9 & 12 & 15.2 & -3.2 & 10.24 \\
\hline 10 & 13 & 15.2 & -2.2 & 4.84 \\
\hline
\end{tabular}

$\sigma 5.7$

$\sigma^{2} 32.84$

Mean 15.2 
Table 13.

Population 2, Group 2, 115 words, final.

\begin{tabular}{|c|c|c|c|c|}
\hline Subject & $\underline{X}$ & $\underline{X}$ average & $\underline{\mathrm{D}}$ & D2 \\
\hline 1 & 11 & 11.2 & -0.2 & 0.04 \\
\hline 2 & 9 & 11.2 & -2.2 & 4.84 \\
\hline 3 & 10 & 11.2 & -1.2 & 1.44 \\
\hline 4 & 13 & 11.2 & 1.8 & 3.24 \\
\hline 5 & 3 & 11.2 & -8.2 & 67.24 \\
\hline 6 & 3 & 11.2 & -8.2 & 67.24 \\
\hline 7 & 29 & 11.2 & 17.8 & 316.84 \\
\hline 8 & 18 & 11.2 & 6.8 & 46.24 \\
\hline 9 & 10 & 11.2 & -1.2 & 1.44 \\
\hline 10 & 6 & 11.2 & -5.2 & 27.04 \\
\hline $\begin{array}{l}\sigma 7.7 \\
\sigma^{2} 59.5 \\
\text { Mean } 11 .\end{array}$ & & & & \\
\hline
\end{tabular}

Table 17 shows the statistics of Population 2, Group 3.

Table 14.

Population 2, Group 3, 146 words, no feedback.

\begin{tabular}{|c|c|c|c|c|}
\hline Subject & $\underline{X}$ & $X$ average & D & D2 \\
\hline 1 & 4 & 16.6 & -12.6 & 158.76 \\
\hline 2 & 4 & 16.6 & -12.6 & 158.76 \\
\hline 3 & 9 & 16.6 & -7.6 & 57.76 \\
\hline 4 & 25 & 16.6 & 8.4 & 70.56 \\
\hline 5 & 44 & 16.6 & 27.4 & 750.76 \\
\hline 6 & 36 & 16.6 & 19.4 & 376.36 \\
\hline 7 & 8 & 16.6 & -8.6 & 73.96 \\
\hline 8 & 17 & 16.6 & 0.4 & 0.16 \\
\hline 9 & 9 & 16.6 & -7.6 & 57.76 \\
\hline 10 & 10 & 16.6 & -6.6 & 43.56 \\
\hline $\begin{array}{c}13.93 \\
2194.27 \\
\text { Iean } 16.6\end{array}$ & & & & \\
\hline
\end{tabular}


Table 18 consolidates information from Tables 4 to 17 .

Table 15.

Consolidated information from Tables 4 to 17.

\begin{tabular}{|c|c|c|c|c|c|}
\hline Treatment & Population & Group & $\underline{\text { Standard Deviation }(\sigma)}$ & Variance (S2) & Mean \\
\hline Indirect & 1 & 1 & 12.56 & 158 & 19 \\
\hline Direct & 1 & 1 & 20.4 & 415.6 & 20.4 \\
\hline Final & 1 & 1 & 12.24 & 149.9 & 15.1 \\
\hline Direct & 1 & 2 & 11.6 & 134.9 & 15.7 \\
\hline Indirect & 1 & 2 & 14.7 & 216.4 & 25.3 \\
\hline Final & 1 & 2 & 9.94 & 98.9 & 14 \\
\hline No Feedback & 1 & 3 & 7.7 & 58.9 & 13 \\
\hline Indirect & 2 & 1 & 5.7 & 32.79 & 12.25 \\
\hline Indirect & 2 & 1 & 6.9 & 47.55 & 16.13 \\
\hline Final & 2 & 1 & 1.6 & 7.1 & 11.5 \\
\hline Direct & 2 & 2 & 8.1 & 65.1 & 16.8 \\
\hline Direct & 2 & 2 & 5.7 & 32.84 & 15.2 \\
\hline Final & 2 & 2 & 7.7 & 59.5 & 11.2 \\
\hline No Feedback & 2 & 3 & 13.93 & 194.27 & 16.6 \\
\hline
\end{tabular}




\section{Appendix G: Data Analysis}

The p-values test the statistical significance of each of the factors; population, treatment, and interactions (between populations and treatment). Since no p-values are less than 0.05 , none of the factors or interactions have a statistically significant effect.

Table 16.

Analysis of Variance for Percentage Mistake - Type III Sums of Squares.

\begin{tabular}{lcccccc}
\hline $\begin{array}{l}\text { Source } \\
\text { Main effects }\end{array}$ & $\underline{\text { Sum of Squares }}$ & $\underline{\text { Df }}$ & Mean Square & $\underline{\text { F-Ratio }}$ & P-Value \\
A: Population & 0.00273248 & $\underline{1}$ & 0.00273248 & 0.48 & 0.4911 \\
B: Treatment & 0.0329546 & 3 & 0.0109849 & 1.92 & 0.1302 \\
& & & & & & \\
Interactions & 0.010022 & 3 & 0.00334065 & 0.58 & 0.6272 \\
AB & & & & & \\
Residual & 0.72199 & 126 & 0.00573008 & & \\
Total (corrected) & 0.768114 & 133 & & & \\
\hline
\end{tabular}

